4

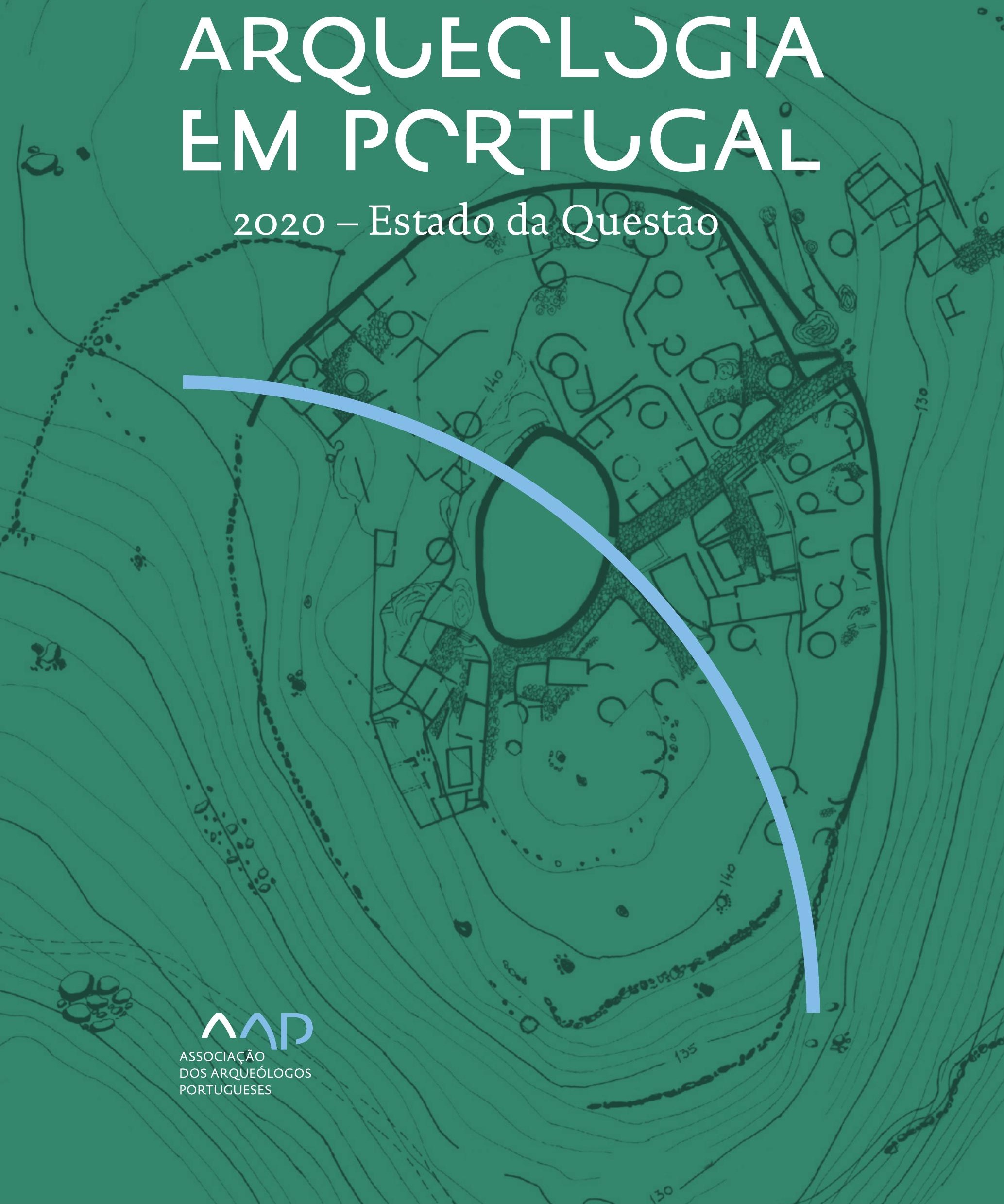


Coordenação editorial: José Morais Arnaud, César Neves e Andrea Martins Design gráfico: Flatland Design

AAP - ISBN: 978-972-9451-89-8

CITCEM - ISBN: 978-989-8970-25-1

Associação dos Arqueólogos Portugueses e CITCEM

Lisboa, 2020

O conteúdo dos artigos é da inteira responsabilidade dos autores. Sendo assim a Associação dos Arqueólogos Portugueses declina qualquer responsabilidade por eventuais equívocos ou questões de ordem ética e legal.

Desenho de capa:

Planta do castro de Monte Mozinho (Museu Municipal de Penafiel).

\section{$\hat{\wedge} \mathrm{P}$}

DOS ARQUEÓLOGOS PORTUGUESES

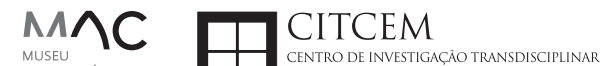
MUSEU
ARQUELLÓGICO
DO CARMO
U.PORTO

FLUP FACULDADE DE LETRAS
UNIVERSIDADE DO PORTO

Apoio

EC para a Ciência 


\section{Índice}

15 Prefácio

José Morais Arnaud

\section{Historiografia e Teoria}

17 Território, comunidade, memória e emoção: a contribuição da história da arqueologia (algumas primeiras e breves reflexões)

Ana Cristina Martins

25 Como descolonizar a arqueologia portuguesa?

Rui Gomes Coelho

41 Arqueologia e Modernidade: uma revisitação pessoal e breve de alguns aspetos da obra homónima de Julian Thomas de 2004

Vítor Oliveira Jorge

57 Dados para a História das Mulheres na Arqueologia portuguesa, dos finais do século XIX aos inícios do século XX: números, nomes e tabelas

Filipa Dimas / Mariana Diniz

73 Retractos da arqueologia portuguesa na imprensa: (in)visibilidades no feminino

Catarina Costeira / Elsa Luís

85 Arqueologia e Arqueólogos no Norte de Portugal Jacinta Bugalhão

101 Vieira Guimarães (1864-1939) e a arqueologia em Tomar: uma abordagem sobre o território e as gentes

João Amendoeira Peixoto / Ana Cristina Martins

115 Os memoráveis? A arqueologia algarvia na imprensa nacional e regional na presente centúria (2001-2019): características, visões do(s) passado(s) e a arqueologia

enquanto marca

Frederico Agosto / João Silva

129 A Evolução da Arqueologia Urbana e a Valorização Patrimonial no Barlavento Algarvio: Os casos de Portimão e Silves

Artur Mateus / Diogo Varandas / Rafael Boavida

\section{Gestão, Valorização e Salvaguarda do Património}

145 O Caderno Reivindicativo e as condições de trabalho em Arqueologia Miguel Rocha / Liliana Matias Carvalho / Regis Barbosa / Mauro Correia / Sara Simões / Jacinta Bugalhão / Sara Brito / Liliana Veríssimo Carvalho / Richard Peace / Pedro Peça / Cézer Santos

155 Os Estudos de Impacte Patrimonial como elemento para uma estratégia sustentável de minimização de impactes no âmbito de reconversões agrícolas Tiago do Pereiro

165 Salvaguarda de Património arqueológico em operações florestais: gestão e sensibilização Filipa Bragança / Gertrudes Zambujo / Sandra Lourenço / Belém Paiva / Carlos Banha / Frederico Tatá Regala / Helena Moura / Jacinta Bugalhão / João Marques / José Correia / Pedro Faria / Samuel Melro

179 Os valores do Património: uma investigação sobre os Sítios Pré-históricos de Arte Rupestre do Vale do Rio Côa e de Siega Verde José Paulo Francisco 
189 Conjugando recursos arqueológicos e naturais para potenciar as visitas ao Geoparque Litoral de Viana do Castelo (Noroeste de Portugal)

Hugo A. Sampaio / Ana M.S. Bettencourt / Susana Marinho / Ricardo Carvalhido

203 Áreas de Potencial Arqueológico na Região do Médio Tejo: Modelo Espacial Preditivo Rita Ferreira Anastácio / Ana Filipa Martins / Luiz Oosterbeek

223 Património Arqueológico e Gestão Territorial: O contributo da Arqueologia para a revisão do PDM de Avis

Ana Cristina Ribeiro

237 A coleção arqueológica do extinto Museu Municipal do Porto - Origens, Percursos e Estudos

Sónia Couto

251 Valpaços - uma nova carta arqueológica

Pedro Pereira / Maria de Fátima Casares Machado

263 Arqueologia na Cidade de Peniche

Adriano Constantino / Luís Rendeiro

273 Arqueologia Urbana: a cidade de Lagos como caso de Estudo Cátia Neto

285 Estratégias de promoção do património cultural subaquático nos Açores. O caso da ilha do Faial

José Luís Neto / José Bettencourt / Luís Borges / Pedro Parreira

297 Carta Arqueológica da Cidade Velha: Uma primeira abordagem

Jaylson Monteiro / Nireide Tavares / Sara da Veiga / Claudino Ramos / Edson Brito /

Carlos Carvalho / Francisco Moreira / Adalberto Tavares

311 Antropologia Virtual: novas metodologias para a análise morfológica e funcional Ricardo Miguel Godinho / Célia Gonçalves

\section{Didáctica da Arqueologia}

327 Como os projetos de Arqueologia podem contribuir para uma comunidade culturalmente mais consciente Alexandra Figueiredo / Claúdio Monteiro / Adolfo Silveira / Ricardo Lopes

337 Educação Patrimonial - Um cidadão esclarecido é um cidadão ativo! Ana Paula Almeida

351 A aproximação da Arqueologia à sala de aula: um caso de estudo no $3^{\circ}$ ciclo do Ensino Básico Luís Serrão Gil

363 Arqueologia 3.o - Pensar e comunicar a Arqueologia para um futuro sustentável Mónica Rolo

377 “Conversa de Arqueólogos" - Divulgar a Arqueologia em tempos de Pandemia Diogo Teixeira Dias

389 Escola Profissional de Arqueologia: desafios e oportunidades Susana Nunes / Dulcineia Pinto / Júlia Silva / Ana Mascarenhas

399 Os Museus de Arqueologia e os Jovens: a oferta educativa para o público adolescente Beatriz Correia Barata / Leonor Medeiros

411 O museu universitário como mediador entre a ciência e a sociedade: o exemplo da secção de arqueologia no Museu de História Natural e da Ciência da Universidade do Porto (MHNC-UP)

Rita Gaspar 
421 Museu de Lanifícios: Real Fábrica de Panos. Atividades no âmbito da Arqueologia Beatriz Correia Barata / Rita Salvado

427 Arqueologia Pública e o caso da localidade da Mata (Torres Novas) Cláudia Manso / Ana Rita Ferreira / Cristiana Ferreira / Vanessa Cardoso Antunes

431 Do sítio arqueológico ao museu: um percurso (também) didático Lídia Fernandes

447 Estão todos convidados para a Festa! E para dançar também... O projecto do Serviço Educativo do Museu Arqueológico do Carmo na $5^{\underline{a}}$ Edição da Festa da Arqueologia Rita Pires dos Santos

459 O “Clã de Carenque”, um projeto didático de arqueologia Eduardo Gonzalez Rocha

469 Mediação cultural: peixe que puxa carroça nas Ruínas Romanas de Troia Inês Vaz Pinto / Ana Patrícia Magalhães / Patrícia Brum / Filipa Santos

481 Didática Arqueológica, experiências do Projeto Mértola Vila Museu Maria de Fátima Palma / Clara Rodrigues / Susana Gómez / Lígia Rafael

\section{Arte Rupestre}

497 Os inventários de arte rupestre em Portugal Mila Simões de Abreu

513 O projeto FIRST-ART - conservação, documentação e gestão das primeiras manifestações de arte rupestre no Sudoeste da Península Ibérica: as grutas do Escoural e Maltravieso Sara Garcês / Hipólito Collado / José Julio García Arranz / Luiz Oosterbeek / António Carlos Silva / Pierluigi Rosina / Hugo Gomes / Anabela Borralheiro Pereira / George Nash / Esmeralda Gomes / Nelson Almeida / Carlos Carpetudo

523 Trabalhos de documentação de arte paleolítica realizados no âmbito do projeto PalæoCôa André Tomás Santos / António Fernando Barbosa / Luís Luís / Marcelo Silvestre / Thierry Aubry

537 Imagens fantasmagóricas, silhuetas elusivas: as figuras humanas na arte do Paleolítico Superior da região do Côa Mário Reis

$55^{1}$ Os motivos zoomórficos representados nas placas de tear de Vila Nova de São Pedro (Azambuja, Portugal) Andrea Martins / César Neves / José M. Arnaud / Mariana Diniz

571 Arte Rupestre do Monte de Góios (Lanhelas, Caminha). Síntese dos resultados dos trabalhos efectuados em 2007-2009 Mário Varela Gomes

599 Gravuras rupestres de barquiformes no Monte de S. Romão, Guimarães, Noroeste de Portugal Daniela Cardoso

613 Círculos segmentados gravados na Bacia do Rio Lima (Noroeste de Portugal): contributos para o seu estudo Diogo Marinho / Ana M.S. Bettencourt / Hugo Aluai Sampaio

631 Equídeos gravados no curso inferior do Rio Mouro, Monção (NW Portugal). Análise preliminar Coutinho, L.M. / Bettencourt, A.M.S / Sampaio, Hugo A.S

645 Paletas na Arte Rupestre do Noroeste de Portugal. Inventário preliminar Bruna Sousa Afonso / Ana M. S. Bettencourt / Hugo A. Sampaio 


\section{Pré-História}

661 O projeto Miño/Minho: balanço de quatro anos de trabalhos arqueológicos Sérgio Monteiro-Rodrigues / João Pedro Cunha-Ribeiro / Eduardo Méndez-Quintas / Carlos Ferreira / Pedro Xavier / José Meireles / Alberto Gomes / Manuel Santonja / Alfredo Pérez-González

677 A ocupação paleolítica da margem esquerda do Baixo Minho: a indústria lítica do sítio de Pedreiras 2 (Monção, Portugal) e a sua integração no contexto regional Carlos Ferreira / João Pedro Cunha-Ribeiro / Sérgio Monteiro-Rodrigues / Eduardo Méndez-Quintas / Pedro Xavier / José Meireles / Alberto Gomes / Manuel Santonja / Alfredo Pérez-González

693 O sítio acheulense do Plistocénico médio da Gruta da Aroeira Joan Daura / Montserrat Sanz / Filipa Rodrigues / Pedro Souto / João Zilhão

703 As sociedades neandertais no Barlavento algarvio: modelos preditivos com recurso aos SIG

Daniela Maio

715 A utilização de quartzo durante o Paleolítico Superior no território dos vales dos rios Vouga e Côa

Cristina Gameiro / Thierry Aubry / Bárbara Costa / Sérgio Gomes / Luís Luís / Carmen Manzano / André Tomás Santos

733 Uma perspetiva diacrónica da ocupação do concheiro do Cabeço da Amoreira (Muge, Portugal) a partir da tecnologia lítica Joana Belmiro / João Cascalheira / Célia Gonçalves

745 Novos dados sobre a Pré-história Antiga no concelho de Palmela. A intervenção arqueológica no sítio do Poceirão I

Michelle Teixeira Santos

757 Problemas em torno de Datas Absolutas Pré-Históricas no Norte do Alentejo Jorge de Oliveira

771 Povoamento pré-histórico nas áreas montanhosas do NO de Portugal: o Abrigo 1 de Vale de Cerdeira Pedro Xavier / José Meireles / Carlos Alves

783 Apreciação do povoamento do Neolítico Inicial na Baixa Bacia do Douro. A Lavra I (Serra da Aboboreira) como caso de estudo Maria de Jesus Sanches

797 O Processo de Neolitização na Plataforma do Mondego: os dados do Sector C do Outeiro dos Castelos de Beijós (Carregal do Sal)

João Carlos de Senna-Martinez / José Manuel Quintã Ventura / Andreia Carvalho / Cíntia Maurício

823 Novos trabalhos na Lapa da Bugalheira (Almonda, Torres Novas) Filipa Rodrigues / Pedro Souto / Artur Ferreira / Alexandre Varanda / Luís Gomes / Helena Gomes / João Zilhão

837 A pedra polida e afeiçoada do sítio do Neolítico médio da Moita do Ourives (Benavente, Portugal)

César Neves

857 Casal do Outeiro (Encarnação, Mafra): novos contributos para o conhecimento do povoamento do Neolítico final na Península de Lisboa.

Cátia Delicado / Carlos Maneira e Costa / Marta Miranda / Ana Catarina Sousa

873 Stresse infantil, morbilidade e mortalidade no sítio arqueológico do Neolítico Final/ Calcolítico ( $4^{\circ}$ e $3^{\circ}$ milénio a.C.) do Monte do Carrascal 2 (Ferreira do Alentejo, Beja) Liliana Matias de Carvalho / Sofia N. Wasterlain 
885 Come together: O Conjunto Megalítico das Motas (Monção, Viana do Castelo) e as expressões Campaniformes do Alto Minho Ana Catarina Basílio / Rui Ramos

899 Trabalhos arqueológicos no sítio Calcolítico da Pedreira do Poio Carla Magalhães / João Muralha / Mário Reis / António Batarda Fernandes

913 O sítio arqueológico de Castanheiro do Vento. Da arquitectura do sítio à arquitectura de um território João Muralha Cardoso

925 Estudo zooarqueológico das faunas do Calcolítico final de Vila Nova de São Pedro (Azambuja, Portugal): Campanhas de 2017 e 2018 Cleia Detry / Ana Catarina Francisco / Mariana Diniz / Andrea Martins / César Neves / José Morais Arnaud

943 As faunas depositadas no Museu Arqueológico do Carmo provenientes de Vila Nova de São Pedro (Azambuja): as campanhas de 1937 a 1967 Ana Catarina Francisco / Cleia Detry / César Neves / Andrea Martins / Mariana Diniz / José Morais Arnaud

959 Análise funcional de material lítico em sílex do castro de Vila Nova de S. Pedro (Azambuja, Portugal): uma primeira abordagem Rafael Lima

971 O recinto da Folha do Ouro 1 (Serpa) no contexto dos recintos de fossos calcolíticos alentejanos

António Carlos Valera / Tiago do Pereiro / Pedro Valério / António M. Monge Soares

\section{Proto-História}

987 Produção de sal marinho na Idade do Bronze do noroeste Português. Alguns dados para uma reflexão

Ana M. S. Bettencourt / Sara Luz / Nuno Oliveira / Pedro P. Simões / Maria Isabel C. Alves / Emílio Abad-Vidal

1001 A estátua-menir do Pedrão ou de São Bartolomeu do Mar (Esposende, noroeste de Portugal) no contexto arqueológico da fachada costeira de entre os rios Neiva e Cávado Ana M. S. Bettencourt / Manuel Santos-Estévez / Pedro Pimenta Simões / Luís Gonçalves

1015 O Castro do Muro (Vandoma/Baltar, Paredes) - notas para uma biografia de ocupação da Idade do Bronze à Idade Média

Maria Antónia D. Silva / Ana M. S. Bettencourt / António Manuel S. P. Silva / Natália Félix

1031 Do Bronze Final à Idade Média - continuidades e hiatos na ocupação de Povoados em Oliveira de Azeméis João Tiago Tavares / Adriaan de Man

1041 As faunas do final da Idade do Bronze no Sul de Portugal: leituras desde o Outeiro do Circo (Beja)

Nelson J. Almeida / Íris Dias / Cleia Detry / Eduardo Porfírio / Miguel Serra

1055 A Espada do Monte das Oliveiras (Serpa) - uma arma do Bronze Pleno do Sudoeste Rui M. G. Monge Soares / Pedro Valério / Mariana Nabais / António M. Monge Soares

1065 São Julião da Branca (Albergaria-a-Velha) - Investigação e valorização de um povoado do Bronze Final

António Manuel S. P. Silva / Paulo A. P. Lemos / Sara Almeida e Silva / Edite Martins de Sá

1083 Do castro de S. João ao Mosteiro de Santa Clara: notícia de uma intervenção arqueológica, em Vila do Conde Rui Pinheiro 
1095 O castro de Ovil (Espinho), um quarto de século de investigação - resultados e questões em aberto

Jorge Fernando Salvador / António Manuel S. P. Silva

1111 O Castro de Salreu (Estarreja), um povoado proto-histórico no litoral do Entre Douro e Vouga

Sara Almeida e Silva / António Manuel S. P. Silva / Paulo A. P. Lemos / Edite Martins de Sá

1127 Castro de Nossa Senhora das Necessidades (Sernancelhe): uma primeira análise artefactual Telma Susana O. Ribeiro

${ }_{1141}$ A cividade de Bagunte. O estado atual da investigação Pedro Brochado de Almeida

1153 Zoomorfos na cerâmica da Idade do Ferro no NW Peninsular: inventário, cronologias e significado Nuno Oliveira / Cristina Seoane

1163 Vasos gregos em Portugal: diferentes maneiras de contar a história do intercâmbio cultural na Idade do Ferro

Daniela Ferreira

1175 Os exotica da necrópole da Idade do Ferro do Olival do Senhor dos Mártires (Alcácer do Sal) no seu contexto regional

Francisco B. Gomes

\section{Antiguidade Clássica e Tardia}

1191 O uso de madeira como combustível no sítio da Quinta de Crestelos (Baixo Sabor): da Idade do Ferro à Romanização Filipe Vaz / João Tereso / Sérgio Simões Pereira / José Sastre / Javier Larrazabal Galarza / Susana Cosme / José António Pereira / Israel Espi

1207 Cultivos de Época Romana no Baixo Sabor: continuidade em tempos de mudança? João Pedro Tereso / Sérgio Simões Pereira / Filipe Santos / Luís Seabra / Filipe Vaz

1221 A casa romana na Hispânia: aplicação dos modelos itálicos nas províncias ibéricas Fernanda Magalhães / Diego Machado / Manuela Martins

1235 As pinturas murais romanas da Rua General Sousa Machado, n. ${ }^{5}$ 1, Chaves José Carvalho

1243 Trás do Castelo (Vale de Mir, Pegarinhos, Alijó) - Uma exploração agrícola romana do Douro

Tony Silvino / Pedro Pereira

1255 A sequência de ocupação no quadrante sudeste de Bracara Augusta: as transformações de uma unidade doméstica Lara Fernandes / Manuela Martins

1263 Os Mosaicos com decoração geométrica e geométrico-vegetalista dos sítios arqueológicos da área do Conuentus Bracaraugustanus. Novas abordagens quanto à conservação, restauro, decoração e datação Maria de Fátima Abraços / Licínia Wrench

1277 “Casa Romana” do Castro de São Domingos (Cristelos, Lousada): Escavação, Estudo e Musealização Paulo André de P. Lemos

1291 A arqueobotânica no Castro de Guifões (Matosinhos, Noroeste de Portugal): O primeiro estudo carpológico

Luís Seabra / Andreia Arezes / Catarina Magalhães / José Varela / João Pedro Tereso 
1305 Um Horreum Augustano na Foz do Douro (Monte do Castelo de Gaia, Vila Nova de Gaia) Rui Ramos

1311 Ponderais romanos na Lusitânia: padrões, formas, materiais e contextos de utilização Diego Barrios Rodríguez

1323 Um almofariz centro-itálico na foz do Mondego

Marco Penajoia

1335 Estruturas romanas de Carnide - Lisboa Luísa Batalha / Mário Monteiro / Guilherme Cardoso

1347 O contexto funerário do sector da "necrópole NO" da Rua das Portas de S. Antão (Lisboa): o espaço, os artefactos, os indivíduos e a sua interconectividade na interpretação do passado Sílvia Loja, José Carlos Quaresma, Nelson Cabaço, Marina Lourenço, Sílvia Casimiro, Rodrigo Banha da Silva, Francisca Alves-Cardoso

${ }_{1361}$ Povoamento em época Romana na Amadora - resultados de um projeto pluridisciplinar Gisela Encarnação / Vanessa Dias

1371 A Arquitectura Residencial em Mirobriga (Santiago do Cacém): contributo a partir de um estudo de caso Filipe Sousa / Catarina Felício

${ }_{1385}$ O fim do ciclo. Saneamento e gestão de resíduos nos edifícios termais de Mirobriga (Santiago do Cacém)

Catarina Felício / Filipe Sousa

1399 Balsa, Topografia e Urbanismo de uma Cidade Portuária Vítor Silva Dias / João Pedro Bernardes / Celso Candeias / Cristina Tété Garcia

1413 No Largo das Mouras Velhas em Faro (2017): novas evidências da necrópole norte de Ossonoba e da sua ocupação medieval Ricardo Costeira da Silva / Paulo Botelho / Fernando Santos / Liliana Nunes

1429 Instrumentos de pesca recuperados numa fábrica de salga em Ossonoba (Faro) Inês Rasteiro / Ricardo Costeira da Silva / Paulo Botelho

1439 A Necrópole Romana do Eirô, Duas Igrejas (Penafiel): intervenção arqueológica de 2016 Laura Sousa / Teresa Soeiro

1457 Ritual, descarte ou afetividade? A presença de Canis lupus familiaris na Necrópole Noroeste de Olisipo (Lisboa)

Beatriz Calapez Santos / Sofia Simões Pereira / Rodrigo Banha da Silva / Sílvia Casimiro / Cleia Detry / Francisca Alves Cardoso

1467 Dinâmicas económicas em Bracara na Antiguidade Tardia Diego Machado / Manuela Martins / Fernanda Magalhães / Natália Botica

1479 Cerâmicas e Vidros da Antiguidade Tardia do Edifício sob a Igreja do Bom Jesus (Vila Nova de Gaia) Joaquim Filipe Ramos

1493 Novos contributos para a topografia histórica de Mértola no período romano e na Antiguidade Tardia Virgílio Lopes

\section{8. Época Medieval}

1511 Cerâmicas islâmicas no Garb setentrional "português": algumas evidências e incógnitas Constança dos Santos / Helena Catarino / Susana Gómez / Maria José Gonçalves / Isabel Inácio / Gonçalo Lopes / Jacinta Bugalhão / Sandra Cavaco / Jaquelina Covaneiro / Isabel Cristina Fernandes / Ana Sofia Gomes 
1525 Contributo para o conhecimento da cosmética islâmica, em Silves, durante a Idade Média Rosa Varela Gomes

1537 Yábura e o seu território - uma análise histórico-arqueológica de Évora entre os séculos VIII-XII José Rui Santos

1547 A encosta sul do Castelo de Palmela - resultados preliminares da escavação arqueológica Luís Filipe Pereira / Michelle Teixeira Santos

1559 A igreja de São Lourenço (Mouraria, Lisboa): um conjunto de silos e de cerâmica medieval islâmica

Andreia Filipa Moreira Rodrigues

1571 O registo material de movimentações populacionais no Médio Tejo, durante os séculos XII-XIII. Dois casos de "sunken featured buildings", nos concelhos de Cartaxo e Torres Novas Marco Liberato / Helena Santos / Nuno Santos

1585 O nordeste transmontano nos alvores da Idade média. Notas para reflexão Ana Maria da Costa Oliveira

1601 Sepulturas escavadas na rocha do Norte de Portugal e do Vale do Douro: primeiros resultados do Projecto SER-NPVD

Mário Jorge Barroca / César Guedes / Andreia Arezes / Ana Maria Oliveira

1619 "Portucalem Castrum Novum" entre o Mediterrâneo e o Atlântico: o estudo dos materiais cerâmicos alto-medievais do arqueossítio da rua de D. Hugo, nํ. 5 (Porto) João Luís Veloso

1627 A Alta Idade Média na fronteira de Lafões: notas preliminares sobre a Arqueologia no Concelho de Vouzela

Manuel Luís Real / Catarina Tente

1641 Um conjunto cerâmico medieval fora de portas: um breve testemunho aveirense Susana Temudo

${ }_{1651}$ Os Lóios do Porto: uma perspetiva integrada no panorama funerário da Baixa Idade Média à Época Moderna em meios urbanos em Portugal

Ana Lema Seabra

1659 O Caminho Português Interior de Santiago como eixo viário na Idade Média Pedro Azevedo

1665 Morfologia Urbana: Um exercício em torno do Castelo de Ourém André Donas-Botto / Jaqueline Pereira

1677 Intervenção arqueológica na Rua Marquês de Pombal/Largo do Espírito Santo (Bucelas, Loures)

Florbela Estêvão / Nathalie Antunes-Ferreira / Dário Ramos Neves / Inês Lisboa

1691 O Cemitério Medieval do Poço do Borratém e a espacialidade funerária na cidade de Lisboa Inês Belém / Vanessa Filipe / Vasco Noronha Vieira / Sónia Ferro / Rodrigo Banha da Silva

1705 Um Espaço Funerário Conventual do séc. XV em Lisboa: o caso do Convento de São Domingos da Cidade Sérgio Pedroso / Sílvia Casimiro / Rodrigo Banha da Silva / Francisca Alves Cardoso

\section{9. Época Moderna e Contemporânea}

1721 Arqueologia Moderna em Portugal: algumas reflexões críticas em torno da quantificação de conjuntos cerâmicos e suas inferências históricas e antropológicas Rodrigo Banha da Silva / André Bargão / Sara da Cruz Ferreira

1733 Faianças de dois contextos entre os finais do século XVI e XVIII do Palácio dos Condes de Penafiel, Lisboa

Martim Lopes / Tomás Mesquita 
1747 Um perfil de consumo do século XVIII na foz do Tejo: O caso do Mercado da Ribeira, Lisboa Sara da Cruz Ferreira / Rodrigo Banha da Silva / André Bargão

1761 Os Cachimbos dos Séculos XVII e XVIII do Palácio Mesquitela e Convento dos Inglesinhos (Lisboa)

Inês Simão / Marina Pinto / João Pimenta / Sara da Cruz Ferreira / André Bargão / Rodrigo Banha da Silva

1775 "Tomar os fumos da erua que chamão em Portugal erua sancta». Estudo de Cachimbos provenientes da Rua do Terreiro do Trigo, Lisboa

Miguel Martins de Sousa / José Pedro Henriques / Vanessa Galiza Filipe

1787 Cachimbos de Barro Caulínitico da Sé da Cidade Velha (República de Cabo Verde)

Rodrigo Banha da Silva / João Pimenta / Clementino Amaro

1801 Algumas considerações sobre espólio não cerâmico recuperado no Largo de Jesus (Lisboa) Carlos Boavida

1815 Adereços de vidro, dos séculos XVI-XVIII, procedentes do antigo Convento de Santana de Lisboa (anéis, braceletes e contas)

Joana Gonçalves / Rosa Varela Gomes / Mário Varela Gomes

1837 Da ostentação, luxo e poder à simplicidade do uso quotidiano: arqueologia e simbologia de joias e adornos da Idade Moderna Portuguesa Jéssica Iglésias

1849 Os amuletos em Portugal - dos objetos às superstições: o coral vermelho Alexandra Vieira

1865 Cerâmicas de Vila Franca de Xira nos séculos XV e XVI Eva Pires

1879 «Não passa por teu o que me pertence». Marcas de individualização associadas a faianças do Convento de Nossa Senhora de Aracoeli, Alcácer do Sal Catarina Parreira / Íris Fragoso / Miguel Martins de Sousa

1891 Cerâmica de Leiria: alguns focos de produção

Jaqueline Pereira / André Donas-Botto

1901 Os Fornos na Rua da Biquinha, em Óbidos Hugo Silva / Filipe Oliveira

1909 A casa de Pêro Fernandes, contador dos contos de D. Manuel I: o sítio arqueológico da Silha do Alferes, Seixal (século XVI) Mariana Nunes Ferreira

1921 O Alto da Vigia (Sintra) e a vigilância e defesa da costa Alexandre Gonçalves / Sandra Santos

1937 O contexto da torre sineira da Igreja de Santa Maria de Loures Paulo Calaveira / Martim Lopes

1949 A Necrópole do Hospital Militar do Castelo de São Jorge e as práticas funerárias na Lisboa de Época Moderna Susana Henriques / Liliana Matias de Carvalho / Ana Amarante / Sofia N. Wasterlain

1963 SAND - Sarilhos Grandes Entre dois Mundos: o adro da Igreja e a Paleobiologia dos ossos humanos recuperados

Paula Alves Pereira / Roger Lee Jesus / Bruno M. Magalhães

1975 Expansão urbana da vila de Cascais no século XVII e XVIII: a intervenção arqueológica na Rua da Vitória no 15 a 17

Tiago Pereira / Vanessa Filipe

1987 Novos dados para o conhecimento do Urbanismo de Faro em época Moderna Ana Rosa 
1995 Um exemplo de Arqueologia Urbana em Alcoutim: o Antigo Edifício dos CTT Marco Fernandes / Marta Dias / Alexandra Gradim / Virgílio Lopes / Susana Gómez Martínez

2007 Palácio dos Ferrazes (Rua das Flores/Rua da Vitória, Porto): a cocheira de Domingos Oliveira Maia

Francisco Raimundo

2021 As muitas vidas de um edifício urbano: História, Arqueologia e Antropologia no antigo Recreatório Paroquial de Penafiel Helena Bernardo / Jorge Sampaio / Marta Borges

2035 O convento de Nossa Senhora da Esperança de Ponta Delgada: o contributo da arqueologia para o conhecimento de um monumento identitário João Gonçalves Araújo / N’Zinga Oliveira

2047 Arqueologia na ilha do Corvo... em busca da capela de Nossa Senhora do Rosário Tânia Manuel Casimiro / José Luís Neto / Luís Borges / Pedro Parreira

2059 Perdidos à vista da Costa. Trabalhos arqueológicos subaquáticos na Barra do Tejo Jorge Freire / José Bettencourt / Augusto Salgado

2071 Arqueologia marítima em Cabo Verde: enquadramento e primeiros resultados do projecto CONCHA

José Bettencourt / Adilson Dias / Carlos Lima / Christelle Chouzenoux / Cristóvão Fonseca / Dúnia Pereira / Gonçalo Lopes / Inês Coelho / Jaylson Monteiro / José Lima / Maria Eugénia Alves / Patrícia Carvalho / Tiago Silva

2085 Trabalhos arqueológicos na Cidade Velha (Ribeira Grande de Santiago, Cabo Verde): reflexões sobre um projecto de investigação e divulgação patrimonial André Teixeira / Jaylson Monteiro / Mariana Mateus / Nireide Tavares / Cristovão Fonseca / Gonçalo C. Lopes / Joana Bento Torres / Dúnia Pereira / André Bargão / Aurélie Mayer / Bruno Zélie / Carlos Lima / Christelle Chouzenoux / Inês Henriques / Inês Pinto Coelho / José Lima / Patrícia Carvalho / Tiago Silva

2103 A antiga fortificação de Quelba / Khor Kalba (E.A.U.). Resultados de quatro campanhas de escavações, problemáticas e perspectivas futuras Rui Carita / Rosa Varela Gomes / Mário Varela Gomes / Kamyar Kamyad

2123 Colónias para homens novos: arqueologia da colonização agrária fascista no noroeste ibérico Xurxo Ayán Vila / José Mạ . Señorán Martín 


\title{
OS AMULETOS EM PORTUGAL - DOS OBJETOS ÀS SUPERSTIÇÕES: O CORAL VERMELHO
}

\author{
Alexandra Vieira ${ }^{\mathrm{T}}$
}

\begin{abstract}
RESUMO
O estudo dos amuletos - objetos com um carácter apotropaico, ou seja, de proteção física e espiritual -, que possuem, por exemplo, o poder de evitar doenças, malefícios ou desgraças, e das superstições a eles associadas, contempla uma parte importante da vida das comunidades: as suas crenças e tradições, que refletem a forma como as pessoas se relacionam com o universo que as rodeia, com a sua interpretação do mundo em que vivem, com as suas práticas do quotidiano. O objetivo deste trabalho passa por tentar conhecer os amuletos elaborados a partir de corais (vermelhos) que se encontram associados às tradições e aos costumes das comunidades portuguesas, durante as épocas moderna e contemporânea.

Palavras-chave: Amuletos, Superstição, Coral Vermelho, Portugal.
\end{abstract}

\begin{abstract}
The transmission of knowledge about amulets - objects with an apotrophic character - physical and spiritual protection, which have, for example, the power to avoid disease, harm or misfortune - and theirs superticions, contemplates an important part of the life of communities: their beliefs and traditions, which reflect how people relate to the universe around them, their interpretation of the world in which they live, their everyday practices. The main purpose of this work is to try to understand the amulets made from (red) corals that are associated with the traditions and customs of the portuguese communities, during the modern and contemporary times.
\end{abstract}

Keywords: Amulets, Superstition, Red Coral, Portugal.

\section{INTRODUÇÃO}

O mundo das crenças populares e superstições sempre nos afigurou como algo fascinante. Estudar essa forma de ver o mundo transportávamo-nos para o imaginário popular, para a explicação do mundo, para a relação com fenómenos cuja explicação científica era praticamente inexistente antes dos séculos XIX/XX. Após a leitura dos dois volumes da coleção Etnografia Portuguesa relativos às superstições, o ingressar no universo das superstições passou a ser um exercício difícil, pois implica entrar num mundo que está intrinsecamente associado ao sofrimento. As difíceis e duras condições de vida, a fome, a elevada taxa de mortalidade, nomeadamente das parturientes e das crianças, o frágil papel social da mulher, remete-nos para uma sociedade moldada pela fome, morte e medo, daí a importância dada aos amuletos pelas diferentes comunidades portugueses e por todos os grupos sociais. $\mathrm{O}$ uso de amuletos "deve-se ao facto de o homem, no seu imaginário sobrenatural, ao ver-se rodeado de seres maldosos, procurar sempre opor-lhes resistência (...). Os amuletos são dotados, segundo o povo, de virtudes maravilhosas contra o mal" (Coelho, 2017, p. 26).

\footnotetext{
“Amuletos ou talismãs são objetos aos quais são atribuídas virtudes sobrenaturais, carregam atrações mágicas de caráter apotropaico e normalmente, o ritual de sua confecção é o que confere a força de seu poder. (...)” (Rodrigues, 2016, p. 73).
}

1. Instituto Politécnico de Bragança; CITCEM - Centro de Investigação Transdisciplinar Cultura, Espaço e Memória; alexandra. vieira@ipb.pt; alexxandra.vieira@gmail.com 
José Leite de Vasconcelos divide os talismãs em amuletos e mascotes ou porte-bonheur: "assim como há objetos que preservam do Mal, também os há que, pela mesma força natural, atraem o Bem. À primeira categoria pertencem os amuletos; à segunda os que os Franceses chamam porte-bonheur (...) e os Portugueses começam a chamar mascotes." Face às suas capacidades "mágicas" os amuletos poderiam ser divididos em duas grandes categorias: pagãos e religiosos, ambos utilizados contra o sobrenatural; fenómenos naturais, doenças; acidentes, perigos e desastres em geral (Vasconcelos, [1985] 2007, p. 279). Há autores que fazem uma distinção entre amuletos e talismãs. Os primeiros protegem do mal, os segundos atraem o bem (a fortuna, a sorte, a saúde e etc.). Há uma certa discrepância nos termos utlizados em relação a José Leite de Vasconcelos, mas no fundo temos duas grandes categorias: 1) objetos, símbolos ou materiais que protegem e afastam o Mal, cuja palavra amuleto parece ser consensual; e 2) objetos, símbolos ou materiais que atraem o Bem, a fortuna e a saúde e para os quais adotaremos a palavra talismã. Existem situações em que o mesmo objeto/símbolo ou material pode exercer esta dupla função. E, por vezes, estes objetos ou símbolos podem ser usados para invocar o Bem, protegendo pessoas, propriedades, negócios ou animais ou podem ser usados para Mal, tal como é o caso do pentagrama, que apontado para cima atrai o bem, mas apontando para baixo, está associada ao mal.

\footnotetext{
"Há amuletos cuja virtude depende ou apenas da sua fôrma , ou ao mesmo tempo da sua fôrma e substancia: figa, sino-saimão, moedas, meia-lua, noz de três esquinas, cornicho; e ha-os cuja virtude depende apenas da sua substancia , ainda que possam ter fôrma definida: contas (de azeviche, de coral), anéis metálicos, ferraduras, mãos de toupeira, dentes, pedras de raio, e outros. Um cornicho actua fundamentalmente pela sua substância; mas pôde ser imitado de osso, e então actua pela sua fôrma. As moedas actuam ou sô por serem de metal, ou porque nelas se representam figuras" (Vasconcelos, 1915, p. 234).
}

Os amuletos servem para proteger pessoas em geral, os animais, a casa e seus pertences, e os campos; e existem em todo o país, com pequenas variações de uma região para a outra (Vasconcelos, 1915, p. 235). O Portugal da Época Moderna e Contemporânea é um mundo de grandes contrastes; se por um lado se encontra profundamente marcado pela religião católica (a devoção a Nossa Senhora é um bom exemplo disso), por outro lado é "como bem notou Francisco Bethencourt, "um universo saturado de magia». Ela era praticada por um sem-número de indivíduos com múltiplas designações (feiticeiros, bruxas, curadores, mezinheiros, benzedores, casa-aberta, adivinhos, magos)" que podiam ser encontrados em qualquer parte do país. Estes indivíduos (homens e mulheres) tinham clientes aos milhares, que eram membros dos mais distintos grupos sociais, dos mais humildes aos mais abastados (Paiva, 2000, pp. 369-370). As curas, as adivinhações, a inclinação de vontades e a elaboração de amuletos faziam parte das funções desses indivíduos (Oliveira, 2013, p. 123). Aqui podemos fazer uma distinção entre amuletos pagãos, feitos por estes indivíduos, dos amuletos cristãos que seriam produzidos pelos ourives e consagrados/benzidos pelos padres.

Por fim, é interessante a crença de que alguns minerais, animais e vegetais possuíam "virtudes naturais" estando associados ao conceito de "magia natural", ou seja, trata-se da manipulação de algo que "com causas naturais produz efeitos extraordinários» (Paiva, 200o, p. 374). Estamos em crer, face às diferentes leituras que fizemos, que o coral é um desses animais e iremos retratar essas diferentes virtudes ao longo deste artigo.

\section{O CORALLIUM RUBRUM}

\begin{abstract}
“Isto é coral vermelho!” A segurar uma pequena amostra do que foi recolhido no fundo do mar, é assim que Joana nos apresenta aquele bem precioso, a rama que os pescadores algarvios costumam trazer agarrada às redes, sem saberem que há quem pague milhares para ter uma joia daquela cor. Aqui só soubemos da sua existência depois de anunciarem a detenção de uma rede ilegal” (...). Joana afirma que o Corallium rubrum, de seu nome científico, vive, sobretudo, em águas profundas do Mediterrâneo e do Atlântico, numa área mais próxima do Estreito de Gibraltar” (Visão, 2014).
\end{abstract}

Corallium rubrum (Lamarck, 1816), Gorgonia nobilis (Linnaeus, 1789), Isis nobilis (Pallas, 1766), Madrepora rubra (Linnaeus, 1758) são alguns dos nomes científicos atribuídos ao coral vermelho (FOA, 2020), pertencente à classe Anthozoa, subclasse Octocorallia, ordem Alcyonacea, subordem Escleraxo- 
nia e família Coralliidae. Existem cerca de 30 espécies de Coralliidae (Jiménez \& Orejas, 2017).

É uma espécie mediterrânea, embora tenha sido detetada em algumas áreas do Atlântico, perto do Estreito de Gibraltar. Costuma formar populações densas, com mais de 40 colónias por metro quadrado, em locais pouco iluminados (Gili \& Diaz, 2001, p. 42). Vive entre os $15 \mathrm{~m}$ e os $300 \mathrm{~m}$ de profundidade. Tem grande longevidade e cresce, em média, apenas um milímetro por ano. É conhecido como o Ouro Vermelho do Mediterrâneo (Visão, 2014). Distribui-se pelo Mediterrâneo Ocidental e Oriental: da Grécia e Tunísia ao Estreito de Gibraltar, incluindo Córsega, Sardenha e Sicília e pelo Atlântico Leste: Sul de Portugal, Marrocos, Canárias e Ilhas de Cabo Verde (FOA, 2020).

O coral vermelho foi explorado de forma irregular, em Portugal, no Algarve, entre 1200 e 1700, até ao colapso da pesca. Nos últimos 300 anos não são conhecidos relatos da sua ocorrência (Boavida $\&$ alii, 2016). Encontra-se documentada a pesca de coral por portugueses no Norte de Marrocos (Cabo Espartel), assim como nas ilhas de Cabo Verde, na segunda metade do século XIX (Zibrowius $\mathbb{\&}$ alii, 1984, p. 165). A referência mais antiga à pesca em Portugal que encontramos no decorrer da nossa pesquisa é a seguinte:

"A apanha de coral, na costa portuguesa, encontra-se documentada, em termos literários, para a Idade Média, designadamente a partir de, pelo menos, meados do século IX. De facto, Ibn Jurdadbih, em 844, mas baseado em informações anteriores, refere, entre outros produtos peninsulares exportados para o Norte de África e o Oriente, o coral obtido nas costas hoje portuguesas" (Gozalbes Cravioto, 1991, p. 31 apud Gomes \& alii, 2015, p. 101).

Durante os reinados de D. Afonso III e D. Dinis, ter-se-iam estabelecido, em Lagos, milaneses para se dedicarem à pesca do coral. Estes dados são referidos por José Bonifácio de Andrade e Silva, mas sem que tenha apresentado documentos que comprovem esta informação. Segundo Gama Barros, o documento mais antigo relativo a esta indústria é um Alvará de 16 de abril de 1462, onde se estabelece o contrato para a pesca do coral "certamente na costa do Algarve” entre D. Afonso V e Filipe Peroço (Torres, 1971). Em 1450 há o registo de uma carta de privilégio ao Infante D. Henrique concedendo-lhe a exclusividade da pesca do coral por D. Afonso V (Viterbo, 1903, p. 316). Lopo de Almeida obtém do rei D. Afonso V, a 22 de abril de 1473, uma carta de concessão da pesca do coral desde o Cabo de Espartel até ao rio Tagadarte (Marrrocos), durante 9 anos, com a exclusividade da apanha do coral na referida área (Rau, 1986, p. 153).

Sabemos que no séc. XVI Lisboa se torna um importante centro comercial onde se estabelecem ourives e lapidários estrangeiros e para onde convergiam metais nobres e pedras preciosas, nomeadamente o coral, vindos dos entrepostos comerciais que Portugal detinha em todo o mundo (MNMC, Joalharia, online).

No Dicionário Geográfico do Padre Luis Cardoso (1747, p. 285) sobre o Algarve diz-se que "Houve antigamente pescaria de coral, que iam buscar a três léguas do mar; era de grande proveito, mas hoje já não se pesca". Efetivamente, cessam os registos documentais relacionados com a pesca do coral. O interesse por esta prática ressurge quando o rei $\mathrm{D}$. João $\mathrm{V}$ concede ao negociante lisboeta Vicente Francisco o privilégio exclusivo, durante cinco anos, da pescaria do coral no Algarve através do Alvará de 2 de novembro de 1711 (Torres, 1971). A pesca do coral vermelho no Algarve volta a ser notícia com a captura de corais através da pesca ilegal, em 2014, o que origina um processo de proteção desta espécie ameaçada.

\footnotetext{
“Os jardins de corais - lugares de refúgio para outras espécies do mundo subaquático - estão ameaçados pela pesca ilegal. Uma lacuna legislativa tem permitido que um dos tesouros marinhos do Algarve, o coral vermelho (Corallium rubrum), esteja a ser capturado e vendido para fabrico de peças de joalharia. O Governo prepara um diploma que interdita a apanha desta espécie rara (...). Os corais vermelhos encontram-se por toda a zona do barlavento, podendo estender-se à Costa Vicentina. "Temos registos de pescadores que dão conta da sua existência ao largo da Carrapateira”, adiantou Jorge Gonçalves (...)" (Revez, 13 de julho de 2020).
}

E, deste modo, ficamos a conhecer alguns apontamentos sobre as características do coral enquanto animal marinho e sobre a pesca do coral em Portugal. 


\section{CORAIS - MEDICINA, AMULETOS E SUPERSTIÇÕES}

"Entre as criaturas aquáticas reais ungidas pelo paganismo greco-romano e acolhidas pelo cristianismo contam-se o peixe, o golfinho, os bivalves e o coral, todos eles considerados, outrora e agora, como animais divinos e benéficos" (Miranda \& Chambel, 2014, p. 81). "Os materiais orgânicos, como coral e pérolas, eram considerados produtos de um longo processo influenciado pelos astros, que lhes conferiam poderes sobrenaturais (Penalva \& Franco, 2016, p. 29).

No Diccionario Histórico de los Artes de la Pesca Nacional, de D. Antonio Sáñez Reguart, Tomo V. 1795, diz-se que o coral tinha ficado conhecido com (...) «el antiquíssimo nombre de "Arbol de Piedra"" (Arbez, 1990, p. 149).

É o universo relativo a estas "árvores de pedra", animais divinos e benéficos, influenciados pelos astros, detentores de poderes sobrenaturais, que vamos abordar nas próximas páginas.

De acordo do José Leite de Vasconcelos, o coral pode ser usado como amuleto, em ramo ou pedaço, ou sob forma de conta ou de figa. É mais comum encontrá-lo trabalhado sob a forma de conta, muitas das vezes formando colares de contas (Vasconcelos, 1929: 50). Para este autor também se usam objetos de coral, simplesmente como joia/adorno, tendo-se perdido a sua propriedade enquanto amuleto e refere ter visto em 1893, "em Lisboa uma senhora com uns brincos feitos de ramos de coral encastoado em ouro: cada brinco seu ramo" (Vasconcelos [1985] 2007, p. 216). Vieira Natividade, sobre Alcobaça, a propósito das superstições associadas ao "culto da pedra", diz que o povo da terra ainda conserva os seguintes amuletos: a pedra do raio; a conta leiteira; a conta de azeviche; as contas do âmbar "para que os dentes nasçam ás creancinhas, e as figas de coral e azeviche, substancias que téem um poder particular contra o mau olhado e outros feitiços" (Natividade, 1917, pp. 123-124). Neste caso o coral é interpretado como sendo uma pedra.

"Tido como possuindo propriedades apotropaicas, capazes de protegerem dos trovões, relâmpagos e tempestades, do mau-olhado, do demónio, dos feitiços, da loucura e demais doenças, mas igualmente de restaurar forças e o sangue, usando-se contra hemorragias, os males das gengivas e dos dentes, a gota, problemas do fígado e intestinos, designadamente lombrigas, a epilepsia, em feridas diversas ou, ainda, para o sucesso dos partos, o coral era tomado moído e sobretudo a sua variedade branca” (Gomes \& alii, 2015, p. 85).

Em relação às propriedades medicinais do coral, vermelho ou branco, o Abade de Baçal cita a obra de Francisco da Fonseca Henriques (Mirandela, 6 de Outubro de 1665 - Lisboa, 17 de Abril de 1731), médico do rei $\mathrm{D}$. João $\mathrm{V}$, que tendo escrito a obra: Medicina Lusitana - Socorro Délfico aos clamores da natureza humana para total profligação de seus males (1710, 1731, 1750) declara que a "agua de sal ammoniaco, destillada por alambique de vidro faz cahir os dentes sem nenhuma dôr; a mesma virtude tem o coral vermelho feito em pó e mettido na cavidade do dente; (...)" (Alves, [1934] 200o, pp. 239-240). Por seu turno, José Leite de Vasconcelos (1929, p. 52), no que concerne esta mesma obra (1731) refere outra das virtudes do coral, como por exemplo, "os pós, tomando-os os meninos antes de outra cousa, quando nascem, os preservam da gota coral" (= epilepsia). Ainda em relação a questões de saúde, JLV recolheu a seguinte informação: em Vila Pouca [de Aguiar] "as mulheres que amamentam usam colar de corais, para se livrarem de dadas nos seios"; um colar de contas de coral, colocado ao pescoço, tira a icterícia; e, por último, quando usado por alguém, se a pessoa estiver triste ou melancólica, o coral torna-se baço, anunciando o estado de ânimo dessa pessoa (Vasconcelos [1985] 2007, p. 216). Para além da analogia da cor vermelha do coral com o sangue, o formato dos ramos de coral remete igualmente para os vasos sanguíneos. Deste modo, utilizado enquanto medicamento, era recomendado para quem tivesse distúrbios relacionados com o sangue: "Tanto em Plínio quanto no Lapidário de Afonso X, o Sábio, há a informação de que a ingestão do coral triturado é benéfica para aqueles que porventura vomitassem ou cuspissem sangue” (Ragazzi, 2016, p. 38).

Enquanto elemento de proteção contra o Mal "diz-se em Vila do Conde que o coral vale o mesmo que o azeviche contra o bruxedo ou mau-olhado. Também se quebra se alguém lança mau-olhado a quem o usa" (Vasconcelos [1985] 2007, p. 216) e livra de quebranto quem o traz no braço ou no pescoço (Vasconcelos, 1929, p. 52). A rainha D. Catarina, mulher de D. João III, possuía nas suas coleções alguns objetos e materiais usados para o parto, como duas línguas de escorpião (dentes de tubarão fossilizados), "uma cabeça de cobra coberta de ouro, ambos 
usados como antídoto para veneno, talvez também como amuleto e com finalidades medicinais, duas pedras de jaspe em forma de coração para estancar o sangue; um ramo de coral para afastar o mau-olhado; (...)" (Buescu, 2019, p. 32).

Éloise Mozzani (1995 - Le Livre des Superstitions. Mythes, Croyances et Légendes - Paris: Robert Laffont, pp. 497-498) menciona existir uma forte tradição desde os cananeus onde o coral tinha a função de "porte-bonheur", passando pela época clássica até à contemporaneidade, no seu uso enquanto amuleto. Em França, Bélgica e Itália o coral é usado principalmente para a proteção das crianças. Outra das crenças sugeridas é que o coral presente numa obra de ourivesaria se perder a cor é sinal de doença. O sentido mais comum em várias tradições é a proteção da doença e de tudo o que está associado ao mal. Nesta obra faz-se referência à sua semelhança com a árvore da vida (como "arbe des eaux") e por isso possui um grande valor simbólico (Informação pessoal de Álvaro Campelo).

A peça portuguesa que melhor parece representar a árvore da vida é o relicário de Santo Lenho, feito de prata e coral, decorado de esmaltes coloridos, uma peça ímpar da joalharia portuguesa. O coral mantém a sua forma natural, de "árvore marinha", a que se atribui o dom da longevidade (MNMC, Joalharia, online). Integra o Tesouro da Rainha Santa, um conjunto de cinco peças constituído pelo relicário, um bordão de peregrina, uma cruz processional, uma imagem-relicário da Virgem com o Menino e um colar (Penalva e Franco, 2016: 28). O ramo de coral, com os seus múltiplos braços destaca-se como peça central deste relicário (Idem: 31). Este grande pólipo de corallium rubrum poderá ser originário da área do mar Mediterrâneo (Carvalho, 2010-2011 apud Penalva \& Franco, 2016, p. 53).

"Os corais foram admirados na Antiguidade, mas sem que que a sua espécie a que pertenciam fosse verdadeiramente conhecida. A sua peculiar morfologia e a diferente reação físico-química quando expostos aos elementos água e ar, tornando-se flexíveis como seres vivos ou rígidos como pedras, colocavam-nos numa mística fronteira entre os reinos vegetal, mineral e animal, sendo a este último que efetivamente pertencem. A mitologia greco-romana forjou-lhes uma origem lendária, fazendo-os resultar da metamorfose das algas pelo contacto com o petrificante sangue da Medusa” (Miranda \& Chambel, 2014, pp. 84-85).
Através de um processo de sincretismo, o sangue da Medusa teria sido posteriormente "transformado" pelo cristianismo para simbolizar o sangue sagrado de Cristo, ambos considerados protetores. O uso de contas de coral em rosários e em colares retratados em volta do pescoço do Santo Menino em pinturas devocionais, é evidência dessa crença (Balzan \& Deidun, 2010, p. 436).

\begin{abstract}
"Os corais tiveram uma dupla utilização medicinal e mágica, (...) como amuletos apotropaicos destinados a afastar o mau-olhado e a proteger os lares e as crianças. Esta última utilização, originalmente pagã, foi conservada pelos cristãos que atribuíram o coral a Jesus Menino (...) Correlativamente, o coral foi considerado profilático e redentor, como o Sangue de Cristo, e, pela sua cristalização e perpétua integridade, foi ainda tomado como metáfora da eternidade da alma do cristão (...)” (Miranda \& Chambel, 2014, pp. 84-85).
\end{abstract}

A este propósito Luísa Penalva e Anísio Franco referem que o uso do coral [vermelho]:

“sublinha este sentido cristológico, pois sabe-se que
este material, ao conjugar, segundo se acreditava na
época, os três reinos da Natureza - animal, vegetal
e mineral —, simbolizava a própria Árvore da Vida,
portanto, a árvore do Novo Testamento e a Vera
Cruz. Também a cor e a estrutura ramificada do coral
reforçavam o sentido do sacrifício do Filho de Deus”
(Penalva \& Franco, 2016, p. 31).

Efetivamente, na iconografia cristã europeia são vários os exemplos de pinturas onde o Menino Jesus se encontra representado com um raminho de coral ao pescoço. Este raminho funcionaria como amuleto, sendo considerado como um elemento de proteção. Também se encontram pinturas em que o Menino Jesus usa ao pescoço um rosário de contas de coral' ${ }^{2}$. Na obra a "Madonna della Vittoria" de An-

\footnotetext{
2. Podemos referir, a título de exemplo, as seguintes pinturas: "La Virgen con Niño", de Francesco Traini (c. 1345); o "o "Retablo de la vida de la Virgen y de San Francisco", Nicolás Francés (1445-146o); a "Virgen de los "Consellers»" de Lluís Dalmau (1428-1461); a "Virgen de la Porciúncula", de Albocácer (Castellón), (c. 1450); "Madonna col bambino", Piero della Francesca (1432-39); "The Trivulzio Madonna" de Andrea Mantegna, (1497). "La Virgen con Niño", Gérard David, (c. 1520). Na obra Sacra Conversazione de Piero della Francesca, 1472, o Menino Jesus usa um colar de contas de coral com um pendente (raminho de coral).
} 
drea Mantegna (1496) podemos ver uma pérgula de folhas, flores e frutos da qual pendem fios de contas de coral e cristal de rocha e um grande ramo inteiro de coral, que não sendo trabalhado/transformado e tendo sido extraído recentemente do mar conservava intacto o seu poder de proteção. Tanto as contas como o ramo de coral proporcionavam uma maior proteção à Virgem e ao Menino Jesus (Bruce-Mitford, 1997).

\footnotetext{
"No Mediterrâneo, achava-se que o coral, como o âmbar, contivesse a "essência da vida" da Deusa-Mãe, que habitava numa "árvore" de coral no oceano. Os povos antigos utilizavam o coral que não tinha sido trabalhado por mãos humanas para se tornarem poderosos em magia. O coral não era polido, cortado, esculpido ou furado. Acreditava-se que qualquer interferência com o coral poderia "matar" as suas energias mágicas, pois achava-se que estava vivo (como de fato estivera)" (Cunningham, 1988, p. 98).
}

Este texto parece ser particularmente significativo se olharmos para o Relicário de Santo Lenho, assim como para os diferentes pendentes sob a forma de ramo de coral utilizados por Cristo, nas pinturas referidas anteriormente, e pelas crianças no seu quotidiano. Ainda hoje se acredita que as pedras em bruto, ou seja, que não foram polidas, perfuradas nem trabalhadas possuem propriedades mágicas mais poderosas.

Em relação a Portugal, afiguram-se menos numerosas as pinturas que representam ramos de coral ou rosários deste mesmo material, mas existem alguns exemplares. Nossa Senhora das Neves, da autoria de Francisco Henriques, é uma pintura a óleo datada de 1509-1511, na qual a Virgem segura o Menino ao colo, que tem à volta do pescoço um colar de contas de coral (Matriznet).

No Museu Nacional de Arte Antiga encontra-se depositado um Rosário com Avé-Marias em contas de coral polido e Padre-Nossos em contas de filigrana de ouro, num total de treze dezenas incompletas, datado de 1601-1650 com $71 \mathrm{~cm}$ de altura (Matriznet) e uma pintura intitulada "Retrato de Senhora com rosário [supostamente em coral], de autor desconhecido (Jooris van der Straeten?), datado de meados do século XVI (Serrão, 2009, p. 28). Será que podemos estabelecer uma relação entre o crescimento da im- portância do Rosário ${ }^{3}$ e a sua produção na ourivesaria, assim como a sua representação nas pinturas? Muitos defuntos eram enterrados com terços ou rosários, alguns em coral. Será que, tal com advoga, Alexandre Ragazzi (2016, p. 39) o raminho de coral em bruto provindo de uma tradição pagã, começou a causar algum desconforto na Igreja, tornando-se as representações do Menino com os pendentes de coral na pintura "cada vez mais raros a partir de meados do Quinhentos. A tendência (...) era para o passado pagão ficar escondido sob a forma de um rosário. De facto, a Contrarreforma se encarregaria de substituir o raminho de coral por esse objeto".

No Museu da Terra de Miranda encontra-se depositado uma pintura a óleo sobre madeira de Santa Catarina de Alexandria, representada com um colar de coral vermelho (1664-1666). No Museu Nacional Machado de Castro existe uma pintura a óleo de Santa Catarina de Siena, que é representada com uma cruz de coral sobre o regaço (1650-170o) (Matriznet). No inventário de 1761 do Tesouro da Catedral de Braga é feita referência a uma casula, datada, provavelmente, de finais do séc. XVI, início do séc. XVII, embora a sua datação não seja consensual. Esta peça realizada com fios de ouro e prata possui duas fiadas de contas de coral e pérolas (Museu da Sé de Braga, em linha). Poderão estas contas de coral e as pérolas terem sido aqui colocadas não só para dar valor a uma peça essencial da liturgia cristã, mas teriam igualmente uma função protetora?

Já em finais do século XIX, José Leite de Vasconcelos (1897, p. 88) refere que é difícil distinguir um amuleto moderno de um objeto de adorno, como por exemplo as contas de colar, neste caso em particular, dos cordões de coral e explica: "No nosso país não só o coral é ainda hoje trazido em collares, ao mesmo tempo como amuleto e como enfeite, mas usão-se supersticiosamente, para certos fins, (...). Posso aqui mencionar igualmente os rosários de contas" (Idem: 154). No fundo, podemos dizer que alguns

\footnotetext{
3. Durante parte da Idade Média a devoção à Virgem Maria invadiu a "piedade cristã desde a Liturgia às Artes e Literatura.” Surgiu, entre outros, a devoção do Rosário. Na Idade Moderna, já num contexto de questionamento da Igreja, a Igreja Católica reage criando a Festa do Rosário, propagando a reza do Rosário e do Terço, entre outros fenómenos. Durante a Época Contemporânea atingiu-se o auge de devoção mariana; foram criados os meses do Rosário e houve uma renovação das Confrarias do Rosário. Outubro é o mês da devoção do Rosário e do Terço (Dias, 1987, pp. 228-229).
} 
materiais nobres, pedras preciosas e semipreciosas, foram "usadas primeiramente como amuletos talismânicos" (Penalva \& Franco, 2016, p. 50), mas vão sendo desprovidos lenta e progressivamente da sua carga mágica/protetora limitando-se a ser observados como um mero enfeite ou adorno, prevalecendo a sua carga estética em detrimento da carga mágico-religiosa.

\section{CORAIS - OBJETOS E CONTEXTOS ARQUEOLÓGICOS}

Um dos maiores desafios deste trabalho consistiu em encontrar amuletos elaborados a partir de coral vermelho e/ou, se possível, contextos arqueológicos associados à sua descoberta. Por possuirmos tão poucos dados sobre o assunto, optámos por registar todas as referências a corais que nos foi possível detetar na pesquisa bibliográfica que realizamos. Não foi possível proceder a uma recolha exaustiva e sistemática, quer em museus, quer nas diversas publicações de arqueologia, quer ainda em relatórios de escavação. Desta forma, possuímos apenas meia dúzia de referências bibliográficas à existência de tais amuletos, assim como algumas indicações de peças e fragmentos de coral em bruto, contas, colares, pulseiras e rosários em coral, que nos foram referidos por alguns colegas, a quem agradecemos, desde já, as suas valiosas indicações.

No povoado fortificado calcolítico do Outeiro Redondo (Sesimbra) foi recolhido na camada 2 um fragmento de coral de cor violeta. Segundo Cardoso e Martins (2017, p. 342):

\footnotetext{
“Quanto ao fragmento de coral, a sua ocorrência vem provar que esta matéria-prima seria já procurada para a confecção de adornos, apesar da colheira ser efectuada em profundidade, eventualmente através de ancinhos que se arrastavam pelo fundo. É provável que a proveniência desta peça se possa situar no litoral algarvio, ou mais além”.
}

Este é o vestígio de um raminho de coral mais antigo em Portugal que conseguimos detetar, até ao momento, através da nossa pesquisa. É possível que uma investigação mais aprofundada venha demonstrar a presença de outros corais em sítios arqueológicos portugueses com cronologias antigas.

Nas intervenções arqueológicas levadas a cabo em Silves [islâmica] tanto na alcáçova como na medina foram detetados materiais provenientes de outras regiões do "al-Andalus, do Norte de África e o do Mediterrâneo Oriental, desde o século VIII ao século XIII" (Portugal Islâmico, 1998, p. 139). Para além dos materiais cerâmicos destacam-se objetos e joias produzidos com recurso a metais preciosos (ouro e prata), marfim, azeviche, osso, e neste caso em particular salienta-se a existência de "amuletos, um deles com a representação da "mão de Fátima" e outro com elemento de coral, (...)" (Idem: 141). Ou seja, no Sul de Portugal, durante a Idade Média já se encontram amuletos produzidos em coral. Esta foi a referência mais antiga a amuletos elaborados a partir de coral, em Portugal, que conseguimos determinar até ao momento.

No Archivo nacional, Visita às Igrejas de Setúbal feita por D. Jorge, filho de D. João II. Anno de 151O. N. 148 da Ordem de Santiago, $f_{2} 2$ e sqq a propósito da "Visitaçam da Jrmida de Nosa Senhora da Troya" aparecem referências a duas peças de coral cuja caracterização passamos a descrever: «it. vymte e sete peças de prata meudjnhas s. olhos e coraçõees e outras muytas cousas em huua argola de prata que pesarã Juutamenre com este coral debaixo três omças cimquo reaes e meio-iij onças b reaes e meio. (...) it. Huu corall encastoado e prata, posto na dita argola que pesou cõ a prata de çima cõ que foy pesado Juutamente o peso que dito he" (Azevedo, 1897, p. 262).

José Leite de Vasconcelos refere que o Prof. Belluci lhe ofereceu um ramo natural de coral, com argola, contra o mau-olhado e que o Sr. Manuel Vieira Natividade lhe ofereceu um amuleto de coral encastoado (Vasconcelos, [1985] 2007, p. 241). Num artigo sobre os amuletos de coral (Vasconcelos, 1929, p. 52) explica que obteve um amuleto "feito de um pedaço de coral, encastoado em prata, e provido de duas argolas, uma fixa, outra móvel, para andar pendurada" no concelho de Arcos, em 1928 e que faz parte da coleção por ele organizada no Museu Etnológico. Não sabemos se estes dois amuletos de coral encastoados serão a mesma peça, descrita em dois textos diferentes ou se correspondem a duas peças distintas.

No Museu Nacional de Arqueologia, encontra-se um "amuleto de coral e casquinha?, composto por três elementos: uma mão fechada com dois dedos abertos a simular chifres, um coração opado tendo de ambos os lados, em relevo, um crucifixo cruzado com uma âncora, e uma haste de coral, que se supõe ter sido fabricado em Lisboa, algures durante a Época Contemporânea (Matriznet). Estará relacionado 
com alguma das peças anteriormente descrita por José Leite de Vasconcelos?

Foram realizadas escavações arqueológicas no Convento de Santana de Lisboa, que permitiram a identificação de estruturas e de um abundante e variado espólio, cuja cronologia se situa entre os finais do século XVI (data de construção do Convento) e o século XVIII. Estamos na presença, entre outros, de objetos produzidos em matérias duras de origem animal que podem ser interpretados com utilitários, de adorno ou devoção. Os mais frequentes utilizam o osso como matéria-prima e os mais raros são produzidos em marfim, madrepérola, carapaça de tartaruga ou coral (Gomes $\&$ alii, 2015, p. 85). O nosso interesse foca-se nos objetos em coral, que neste caso em particular se cingem a duas pequenas contas de cor vermelho rosado, de formas diferentes e contextos distintos: uma conta esférica com $4 \mathrm{~mm}$ de diâmetro que foi exumada de uma fossa (fossa 3 ) e uma conta cilíndrica com $8 \mathrm{~mm}$ de comprimento, proveniente de um nível arqueológico com inúmeros restos orgânicos. A dimensão destas contas, de dimensão muito reduzida, "parece afastar a hipótese de se tratar de elementos de rosários ou de terços e terem feito parte de brincos ou de outros adereços, podendo, nomeadamente, terem sido fixados a vestidos" (Idem: 100).

Mário Varela Gomes crê "ser possível que pequenas contas de coral, de cor rosada, exumadas nas ruínas da Igreja de Santa Maria do Castelo (Torres Novas) pertencessem a um rosário" (Gomes $\&$ alii, 2015, p. 101).

De acordo com a informação pessoal de António Marques, da Câmara Municipal de Lisboa: "Existe um pendente de prata com coral que foi encontrado nas escavações dos Terraços do Carmo. Trata-se de espólio funerário que estava associado a um enterramento, possivelmente dos séculos XVI ou XVII". Nas escavações arqueológicas da Igreja do Convento do Carmo foram exumadas, a par de muitos outros objetos, duas peças elaboradas a partir de coral: a) uma pulseira do século XVII formada por 42 contas de coral branco e 10 contas de metal com 3,5 mm de diâmetro; b) um colar de coral vermelho dos séculos XVI-XVII, composto por 121 contas com 3 mm de diâmetro e 3 contas cilíndricas com o comprimento de $26,5 \mathrm{~mm}$ e $5 \mathrm{~mm}$ de diâmetro médio (Ferreira \& Neves, 2005, pp. 607-608). O contexto funerário destes objetos relaciona-se com a escavação das Capelas da Cabeceira da Igreja (onde foram detetadas 43 sepulturas), bem como da nave principal e transepto (onde se registaram cerca de mil e quinhentas inumações). O espólio proveniente das sepulturas foi divido em diferentes grupos/categorias, nomeadamente: sumptuária (objetos de adorno); mágico-religiosos; indumentária, armas e diversos. Estamos em crer que neste caso em particular, tanto o colar como a pulseira terão sido catalogados como objetos de adorno, mas efetivamente um objeto pode ter várias funções. Neste caso, poderiam ser objetos de adorno com um carácter mágico-religioso (Figura 1 e 2).

A Igreja da Misericórdia de Almada foi intervencionada nos inícios dos anos 80 do passado século, e, novamente, em 2013. Foram escavadas diversas sepulturas onde foram detetados restos osteológicos e diverso espólio arqueológico. Tanto os enterramentos como a utilização do espaço sepulcral podem ser balizados entre os séculos XVI e XVIII (Dias \& alii, 2017, p. 1675). Na sepultura 9, uma fossa simples, sub-rectangular, escavada no solo, detetaram-se diversos indivíduos. Aqui foram exumadas 110 contas esféricas e ovais e 12 contas torneadas, em osso e identificou-se ainda uma conta em coral, de coloração rosa e tom claro (Idem: 1679). Nas escavações realizadas no interior da Capela de Nossa Senhora dos Passos foram aí encontrados, para além de muitos outros objetos, uma conta em coral e um fragmento que pode ter pertencido a um qualquer tipo de adorno (Dias \& alii, 2017, p. 1681).

A exposição "Os Expostos da Roda da Santa Casa da Misericórdia de Lisboa”, é acompanhada de um catálogo onde se regista o aparecimento de uma conta de coral: Manuscrito e conta - Papel e coral. Portugal 179. Documento ${ }^{\circ} 16$.

“Este menino nasceu no dia 28 do mes de Outubro deste
presente ano de 1792. Foi baptizado em cas[a] a nascen-
ça por vir de perigo e faltam-lhe OS santos oleos. Ha-de-
-se chamar Jose. Leva por sin[a]l um coral. E leva vestido
um manteu' preto, uma envolta de chita, [e] uns man-
guitos de baeta alvadia”" (Os expostos..., 2001, p. 56).

Os "sinais de expostos" são na sua maioria manuscritos acompanhados por um ou mais objetos que teriam tido algum tipo de significado para as famílias que se viam obrigadas deixar os seus filhos ao cuidado da Misericórdia de Lisboa. Estamos na presença de: 
"artefactos de significado particularmente afectivo, em diversos casos de sentido simbólico, mágico e religioso. De facto, o valor real destas peças reside, fundamentalmente, na sua importância como forma de identificação da criança, podendo os familiares, na posse de fragmentos dos sinais deixados na Roda, comprovarem as suas afinidades de parentesco no ato de recuperação dos seus entes queridos” (Morna \& alii, 2001, p. 12).

A maior parte dos sinais escritos têm como suporte o papel, mas também podemos encontrar outros tipos de suportes (têxtil, metal, coral, etc.) que os acompanham (Reis, 2016, p. 90). Os materiais nobres, semi-nobres ou exóticos têm uma menor expressão. A diversidade de sinais, de formas e materiais demonstram-nos a preocupação de colocar a criança sob proteção: "Assim as figas e os trevos de quatro folhas funcionam como talismãs que reforçam a protecção pedida para aquela criança, (...)” (Reis, 2016, p. 128). Tartaruga, marfim, madrepérola, corais e osso eram utilizados em amuletos e talismãs, apelando a uma protecção mágica para a criança. Podem aparecer sozinhos ou acompanhados por outros "elementos de simbologia cristã, reforçando um desejo de protecção de ambas as esferas" (Idem: 267).

Em Lagos, nas escavações da lixeira medieval-moderna, onde apareceram esqueletos de escravos africanos, foi encontrado um coral vermelho (Figura 3). Está exposto no Núcleo Museológico da Rota da Escravatura (informação pessoal de Elena Morán). O Valle da Gafaria situa-se em Lagos (Santa Maria, Lagos) junto à Porta dos Quartos, a poucos metros da Cerca Nova que foi mandada construir por D. João III (Neves \& alii, 2011, pp.29;31).Éneste local que se nota um crescimento urbano durante a época medieval e moderna, tornando-se Lagos num centro comercial com bastante dinamismo durante a Idade Média. $O$ fragmento de coral que destacamos no nosso trabalho foi descoberto durante a escavação dos depósitos que constituem o contexto da "lixeira" moderna de Lagos (Almeida $\&$ alii, 2012, p. 95):

"um conjunto estratigráfico composto por centenas de unidades de terreno, correspondentes a sucessivos despejos antrópicos intencionais de diversos desperdícios domésticos e urbanos que constituíram montículos de dimensões variáveis que se recobriam/justapunham, formando níveis lenticulares, que incluiriam sobretudo muita matéria orgânica" (Neves \& alii, 2011, p. 33).
Esta lixeira urbana, acumulada em Época moderna no interior e em torno de um "boqueirão". revelou a presença de 155 de esqueletos humanos (Neves $\mathbb{8}$ alii, 2011, p. 29). Nestes depósitos, e à medida que se acumulavam os lixos, foram sendo depositados os corpos dos escravos (Idem: 36 ) que chegavam a Lagos vindos de África. Este sítio ficou conhecido como o "Poço de Negros" e está datado por carbono 14, desde meados do séc. XV (Almeida \& alii, 2012, p. 96). Em Lagos, por volta de 1555, será criada a "Confraria dos Homens Pretos da Senhora do Rosário”, na igreja de S. Sebastião (Neves \& alii, 2011, p. 43) (Figura 4). O sítio do Cabo Raso é o local do naufrágio do navio florentino Grande Princesa da Toscânia ("Gran Principessa di Toscana”), que ocorreu em 1696. Alguns documentos reportam a situação que levou ao afundamento do navio, dos quais apenas vamos retirar um pequeno excerto:

“(.) Paul Methuen (1689) refere que o correio inglês
voltou a falhar nessa semana, devido ao mau tempo,
que havia estado tempestuoso vinte e cinco dias sem
interrupção. Refere ainda que um grande navio legor-
nês chamado a Grande Princesa da Toscânia, comanda-
do pelo capitão Benoict Prasca de Livorno, naufragou
no Cabo da Roca a uma légua de distancia de Cascais,
tendo-se afogado a maior parte da tripulação, no dia de
Santo André, à meia noite, depois de três dias de tem-
pestade que lhes fez gritar Misericórdia, que lhes dei-
tou abaixo todos os mastros e que os fez lançar à costa
com três ancoras ao mar que não impediram o navio de
naufragar porque o fundo era muito mau (...)” (Car-
doso, 2012, p. 11).

A primeira indicação que nos foi dada sobre este sítio foi de Guilherme Cardoso que viu ser retirado coral vermelho de um naufrágio do século XVII, junto ao Cabo Raso, em Cascais. No seguimento desta informação contactámos Mário Jorge Almeida, do Museu Nacional de Arqueologia, que afirmou ter encontrado pequenos fragmentos de coral entre os 5 e os $10 \mathrm{~mm}$ no Cabo Raso (informação pessoal de Mário Jorge Almeida). Mas já antes em 1967, uma equipa de mergulhadores tinha recuperado neste mesmo local, a par de outros objetos, cinco fragmentos de coral vermelho (Cardoso, 2012, p. 9). Os vinte e dois elementos de coral, recuperados em 1968, por Soares Branco (coleção particular) consiste num conjunto de contas furadas e "trabalhadas", embora se note alguma erosão associada à dinâmica 
dos sedimentos arenosos dos fundos sobre os materiais (informação pessoal de Mário Jorge Almeida). Em 1996, Mário Jorge Almeida e alguns amigos recuperaram um vasto conjunto de artefactos - pratos de estanho, compasso, arma, moedas de prata, balas de mosquete, peças de chumbo, - a par de 35 fragmentos de coral vermelho (Cardoso, 2012, p. 10).

Como vimos, as recolhas efetuadas em diferentes momentos no local do naufrágio deste navio, vindo da Toscânia, uma região de Itália cuja capital é Florença, trouxeram à superfície vários fragmentos de coral, na sua forma natural, ou seja, em bruto, com ramos de pequenas dimensões ou ainda contas furadas. Ambos poderiam vir a integrar diferentes tipos de joias ou amuletos, num trabalho de manufatura dos ourives e joalheiros portugueses, que adquiriam esta matéria-prima fora de Portugal, atendendo ao declínio da pesca do coral em Portugal durante este período (Figura 5).

Apesar do nosso estudo se focar essencialmente no coral vermelho, registam-se corais brancos no âmbito de escavações subaquáticas no leito do rio Ave, realizadas por Ivone Magalhães em 2005, onde foram exumados alguns fragmentos de corais brancos (dendrophyllia sp.), no local onde teriam existido os estaleiros navais de Vila do Conde, nos séculos XV e XVI, junto a um paredão. Estes achados surgem aquando da construção do cais para a réplica da nau quinhentista, na área da ensecadeira e foram encontrados no Cais das Lavandeiras, em Vila do Conde. Este importante porto comercial dos séculos XV e $\mathrm{XVI}$, onde se procedeu igualmente à construção naval, detinha um volumoso trânsito comercial interno, com o Norte da Europa (Antuérpia) e com o Mediterrâneo (informação pessoal de Pedro Brochado de Almeida) (Figura 6).

Segundo Amélia Polónia “(...) cremos estar na posse de dados que apontam para uma notória posição de relevo assumida pela frota vilacondense no conjunto do poder naval do reino, no que se refere à capacidade de transporte marítimo, na segunda metade do século XVI (Polónia, 1999, p. 367). Não sabemos a proveniência do coral branco, nem a que fins se destinava, mas é plausível, com base na informação exposta anteriormente, que fosse utilizado para fins medicinais, reduzido a pó, ou na produção de joias - contas utilizadas em brincos, colares ou pulseiras.

O Museu do Mar Rei D. Carlos, em Cascais, também possui nas suas Reservas Museológicas alguns exemplares de corais brancos (informação pessoal de Maria Fernanda Costa, Museu do Mar de Cascais).

\section{CONSIDERAÇÕES FINAIS}

Quando demos início ao nosso estudo sobre os amuletos, estávamos longe de imaginar a riqueza e diversidade que este tema encerra em si mesmo. O nosso primeiro trabalho foi sobre as pedras de raio (Vieira, 2019) no qual pudemos perceber como as comunidades portuguesas interpretavam estes vestígios pré-históricos e a forma como os "integravam" no seu quotidiano.

Este segundo trabalho, sobre os corais, levou-nos para um mundo completamente distinto do anterior. É um mundo relacionado com a medicina, com o mar, com a pesca, com a ourivesaria/joalharia, com a arte, permitindo aceder a algumas fases deste saber-fazer que contempla determinadas materialidades; um conhecimento específico sobre a transformação desses materiais em objetos; a adoção de um conjunto determinado de formas; a sua consagração enquanto objeto de proteção (amuleto) e, por fim, a sua utilização no dia-a-dia por crianças e adultos.

Estamos assim na presença de objetos com uma carga mágica-religiosa-simbólica muito expressiva, mas igualmente marcada pela qualidade estética dos objetos produzidos a partir do coral vermelho (e branco). É um tema que se ramifica, permitindo a análise de diversos subtemas, o que se torna muito aliciante.

Em suma, sabemos que existiu a pesca de coral vermelho em Portugal e que foram confecionadas peças a partir desse material (pescado cá ou importado do Mediterrâneo) por ourives/joalheiros/artesãos ao longo da Época Moderna e Contemporânea. Existem evidências da existência de raminhos de coral utilizados como pendentes pelas crianças, como forma de proteção, contas de colar em coral vermelho utilizadas para a confeção de rosários ou terços, pulseiras, colares, brincos, peças de tecido, entre outros. Vimos que muitas destas peças foram representadas na arte, nomeadamente na pintura e que possuem um carácter profano, como as figas de coral, por exemplo; religioso, como os rosários e terços; e, simultaneamente profano e religioso, como os raminhos de coral. Estamos em crer que as contas utilizadas em colares, pulseiras e brincos, poderiam ter tido, pelo menos no início da época moderna, um duplo carácter de proteção/adorno. Estes objetos não só acompanham crianças e adultos em vida, 
como surgem em contextos de enterramento, acompanhando-os também na morte.

Daremos continuidade à investigação dos corais em Portugal, investindo numa pesquisa bibliográfica mais exaustiva; procurando mais exemplares da representação destes objetos em pinturas, esculturas e peças de ourivesaria; sistematizando a inventariação das peças que se encontram em museus ou que surgem em contextos arqueológicos; procurando perceber com maior profundidade a pesca do coral vermelho nas costas algarvias. São estes alguns dos caminhos de pesquisa que o corallium rubrum nos aponta.

\section{AGRADECIMENTOS}

Alexandre Gonçalves, Álvaro Campelo, António Marques (Câmara Municipal de Lisboa), Carla Azevedo (BPMP), César Neves (AAP - MAC), Cónego Carlos César Chantre (Paróquia de S. Pedro de Faro), Elena Morán (Câmara Municipal de Lagos), Guilherme Cardoso, Lois Ladra, Luísa Penalva (MNAA), Maria Fernanda Costa (Museu do Mar de Cascais), Mário Jorge Almeida (MNA), Miguel Almeida (Dryas Octopetala), Miguel Rodrigues (DRCN), Pedro Brochado de Almeida (Câmara Municipal de Vila do Conde), Sandra Santos e Tânia Manuel Casimiro.

\section{BIBLIOGRAFIA}

ALMEIDA, Miguel; NEVES, Maria João; FERREIRA, M. Teresa, (2012) - Intervenção de arqueologia preventiva-Parque de Estacionamento do Anel Verde (Santa Maria, Lagos, Faro). Março de 2012 Relatório final: parte 1.

ALVES, Francisco, (200o [1934]) - Memórias Arqueológico-Históricas do Distrito de Bragança. Tomo VII -Arqueologia, Etnografia e Arte. Porto.

ARBEX, Juan Carlos, (1990) - Pescadores Españoles, Secretaria General de Pesca Maritima. Madrid: Ministerio de Agricultura, Pesca y Alimentacion, volume 2.

AZEVEDO, P. A., (1897) - Estudos sobre Tróia de Setúbal. 4. Nossa Senhora de Tróia nos sécs. XV e XVI. In O Archeologo Português, 3. Lisboa, pp. 257-265.

BALZAN, Francesca; DEIDUN, Alan, (2010) - Notes for a history of coral fishing and coral artefacts in Malta. The Malta Historical Society.

BOAVIDA, Joana; \& alii. (2016) - A Well-Kept Treasure at Depth: Precious Red Coral Rediscovered in Atlantic Deep Coral Gardens (SWPortugal) after 300 Years. PLOS ONE. 11 (2) https://doi.org/10.1371/journal.pone.0150654
BRUCE-MITFORD, Miranda, (1997) - El Libro Ilustrado de Signos Y Simbolos. Editorial Diana.

BUESCU, Ana Isabel, (2019) - D. Beatriz de Portugal, a Infanta Esquecida (1504-1538). Lisboa: Letras \& Diálogos.

CARDOSO, João Luís; MARTINS, Filipe, (2017) - O Povoado Pré-histórico do Outeiro Redondo (Sesimbra): resultados das campanhas de escavação de 2013 e 2014. Estudos Arqueológicos de Oeiras. Oeiras: Câmara Municipal de Oeiras. 23. pp.233-392.

CARDOSO, João Pedro, (2012) - Sobre os destroços da Gran Principessa di Toscana, naufragada em 1696 nas imediações do Cabo Raso, Cascais. Cascais: Junta de Freguesia.

CARDOSO, Luis, (1747) - Dicionário Geográfico ou Notícia Historica de todas as Cidades, Villas, Lugares e Aldeas, Rios, Ribeiras, e Serras dos Reynos de Portugal, e Algarve, com todas as cousas raras, que nelles se encontraõ, assim antigas, como modernas. Lisboa: Na Regia Officina Sylviana e da Academia Real. Tomo I.

Portugal Islâmico. (1998) - Catálogo da Exposição: Os Últimos Sinais do Mediterrâneo, Lisboa: Min.Cult.; IPM; MNA.

COELHO, Miguel Alexandre Batista, (2017) - Religiosidade popular: tradições, práticas e mitos. Tese de doutoramento. Lisboa: Universidade Católica Portuguesa.

CUNNINGHAM, Scott, (1988) - Enciclopédia de Cristais, Pedras Preciosas e Metais. Coleção Gaia. Alemdalenda.

DIAS, Geraldo Coelho, (1987) - A devoção do povo português a Nossa Senhora nos tempos modernos. In Revista da Faculdade de Letras. História, №. 4, pp. 227-256.

DIAS, Vanessa; CASIMIRO, Tânia Manuel; GONÇALVES, Joana (2017) - Os bens terrenos da Igreja da Misericórdia (Almada): séculos (XVI-XVIII). In Arqueologia em Portugal. 2017-Estado da Questão, coord. ed. ARNAUD, J. M.; MARTINS, A. Lisboa: Associação dos Arqueólogos Portugueses. pp. 1675-169o.

FERREIRA, F. E. R.; NEVES, M. C. M., (2005) - Intervenção Arqueológica na Igreja do Convento do Carmo. In ARNAUD, J. M.; FERNANDES, C. V. (coord.), Construindo a Memória. As Colecções do Museu Arqueológico do Carmo. Lisboa: Associação dos Arqueólogos Portugueses, pp. 58o-6o9.

FOA - Food and Agriculture Organization of the United Nations. Fisheries and Aquaculture Department. Species Fact Sheets: Corallium Rubrum (Linnaeus, 1758) 2020. Disponível em: http://www.fao.org/fishery/species/3611/en

GILI, J. M. \& DIAZ, D., (2001) - El coral rojo. Investigación y Ciencia, 299: 42-43.

GOMES, Mário Varela; GOMES, Rosa Varela; GONÇALVES, Joana, (2015) - Objectos produzidos em matéria animal, do Convento de Santana, de Lisboa. In Actas do I Encontro de Arqueologia de Lisboa, Uma Cidade em Escavação. Lisboa: Centro de Arqueologia de Lisboa. 
JIMÉNEZ, C., \& OREJAS, C., (2017) - The Builders of the Oceans. Part II: Corals from the Past to the Present (The Stone from the Sea). Springer International Publishing.

MIRANDA, Adelaide; CHAMBEL, Pedro, (2014) - Bestiário Medieval. Perspectivas de Abordagens. Lisboa: Instituto de Estudos Medievais.

MORNA, Teresa Freitas; BRITO, Maria Filomena; MANOEL, Francisco d'Orey; COLEN, Maria Luísa Barbosa, (2001) - O acolhimento de crianças enjeitadas da Misericórdia de Lisboa. In Os expostos da Roda da Santa Casa da Misericórdia de Lisboa. Lisboa: Museu de São Roque e Arquivo Histórico/Biblioteca.

Museu da Sé de Braga [em linha] (1999)-Tesouro do Museu da Sé Catedral de Braga. Disponível em: http://www.geira. pt/Msebraga/Coleccoes/casula_frontal.html

Museu Nacional Machado de Castro - Joalharia [em linha]. Disponível em http://www.museumachadocastro.gov.pt/ pt-PT/coleccoes/PrintVersionContentDetail.aspx?id=616

Museu Nacional Machado de Castro-Ourivesaria [em linha]. Disponível em: http://www.museumachadocastro.gov.pt/ pt-PT/coleccoes/Ourivesaria/ContentDetail.aspx?id=180

NATIVIDADE, M. Vieira, (1917) - O Povo da Minha Terra - Notas e registos de etnografia alcobacense - Crenças e superstições - A Pedra. Sep. de: Terra portuguesa: revista ilustrada de arqueologia artistica e etnografia. Lisboa: Annuario Commercial.

NEVES, Maria João, ALMEIDA, Miguel M, FERREIRA, M. Teresa. (2011) - História de um arrabalde durante os séculos XV e XVI: "o Poço dos Negros" em Lagos (Algarve, Portugal) e o seu contributo para o estudo dos escravos africanos em Portugal. In A Herança do Infante. Lisboa: Centro de Estudos dos Povos e Culturas de Expressão Portuguesa pp. 29-46.

OLIVEIRA, Ricardo Pessa de (2013) - Pobres e perseguidos: os mágicos em Pombal (séculos XVII e XVIII). In I Congresso Histórico Internacional. As Cidades na História: População. III - Cidade Moderna I. Câmara Municipal de Guimarães.

PAIVA, José Pedro, (200o) - A magia e a bruxaria. In AZEVEDO, Carlos Moreira (Dir.) - História Religiosa de Portugal. Lisboa: Círculo de Leitores. vol. II, pp. 369-375.

PENALVA, Luísa; FRANCO, Anísio, (2016) - Matéria e Devoção. O Tesouro da Rainha Santa. In O Tesouro da Rainha Santa. Imagem e poder (coord. Luísa PENALVA). Lisboa: Museu Nacional de Arte Antiga, Lisboa.

POLÓNIA, Amélia, (1999) - Vila do Conde. Um porto nortenho na expansão ultramarina quinhentista. Tese de doutoramento. Faculdade de Letras da Universidade do Porto.

RAGAZZI, Alexandre, (2016) - Entrecruzamentos Culturais: Superstição, Mito e Fé nos Amuletos de Coral. In Anais do XXXVI Colóquio do Comitê Brasileiro de História da Arte: Arte em Ação, Campinas-SP. 4-6 de outubro. Rio de Janeiro: Comitê Brasileiro de História da Arte - CBHA, 2016.
RAU, Virgínia, (1986) - Aspectos do 'trato' da 'Adiça' e da 'pescaria' do 'coral' nos finais do século XV. In Estudos de História Medieval. Lisboa: Editorial Presença. pp. 142-151.

REIS, Maria José, (2016) - Ler sinais: os sinais dos expostos da Santa Casa da Misericórdia de Lisboa (1790-1870). Tese de doutoramento, História (Sociedades e Poderes), U. L., ISCTE- Instituto Universitário de Lisboa, UCP, UE.

REVEZ, Idálio. Corais vermelhos do Algarve: um "tesouro" a saque e sem protecção legal (em linha). Publico. 13 de Julho de 2020. Disponível em: https://www.publico. $\mathrm{pt} / 2020 / 07 / 13 /$ local/noticia/corais-vermelhos-algarve-tesouro-saque-proteccao-legal-1924281

RODRIGUES, Andreia, (2016) - O poder dos amuletos antigos: afastando a melancolia. Anais do XXXVI Colóquio do Comitê Brasileiro de História da Arte: Arte em Ação, Campinas-SP. 4-6 de outubro. Rio de Janeiro: Comitê Brasileiro de História da Arte - CBHA.

TORRES, Ruy d'Abreu, (1971) - Coral. In Joel SERRÃO (dir.) Dicionário de História de Portugal. Lisboa: Iniciativas Editoriais.

SERRÃO, Vítor, (2009) - A Pintura Maneirista e Proto-Barroca. In Arte Portuguesa, da Pré-história ao Século XX (coord. Dalila RODRIGUES) vol. 11. Vila Nova de Gaia: Fubu Editores.

VASCONCELOS. José Leite de, (1897) - Religiões da Lusitânia: na parte que principalmente se refere a Portugal. Lisboa: Imprensa Nacional. Vol. 1.

VASCONCELOS. José Leite de, (1915) - História do Museu Etnológico Português (1893-1914). Lisboa. Imprensa Nacional.

VASCONCELOS. José Leite de (1929) - Amuletos de coral. In Boletim de Etnografia, Museu Etnológico Português, IV, Lisboa. pp. 50-53.

VASCONCELOS. José Leite de (1985] 2007) - Etnografia Portuguesa. Volume IX. Lisboa: Imprensa Nacional-Casa da Moeda.

VIEIRA, Alexandra (2019) - Raios e Coriscos. In Revista Memória Rural, nº 2, Museu da Memória Rural Carrazeda de Ansiães: Câmara Municipal de Carrazeda de Ansiães.

Visão - Em busca do coral vermelho (em linha). 29.07.2014. Disponível em: https://visao.sapo.pt/atualidade/ambiente /2014-07-29-em-busca-do-coral-vermelhof791208/\#\&gid $=0 \&$ pid $=1$

VITERBO, Francisco Sousa, (1903) - A pesca do coral no século XV. In Archivo Historico Portuguez, vol. I. Lisboa. pp. 315-320.

ZIBROWIUS H, MONTEIRO MARQUES V, GRASSHOFF M., (1984) - La Repartition du Corallium rubrumdans l'Atlantique (Cnidaria: Anthozoa: Gorgonaria). In Téthys. 11. pp.163-170. 

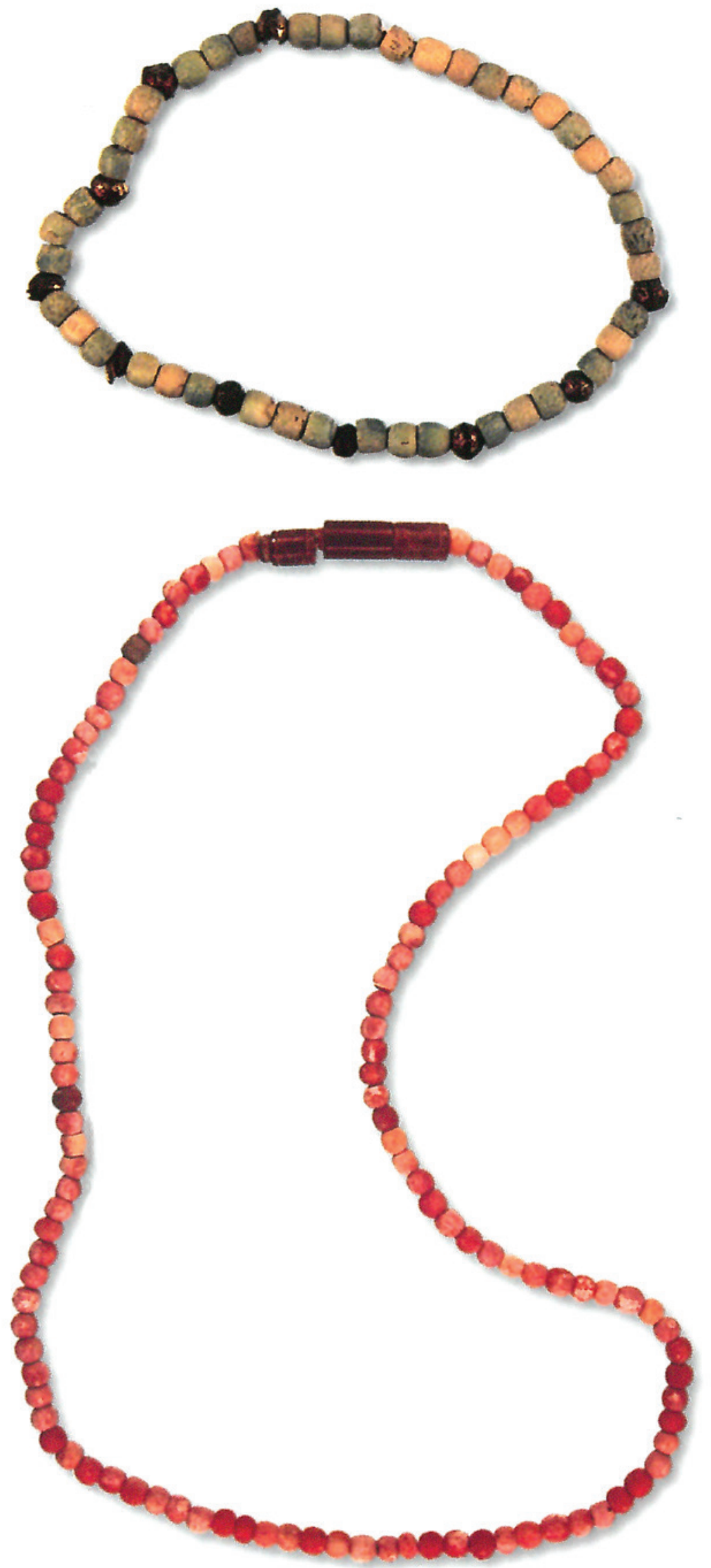

Figuras 1 e 2 - Pulseira de coral branco (em cima) e colar de coral vermelho (em baixo). Fotografias cedidas pelo Museu Arqueológico do Carmo. 


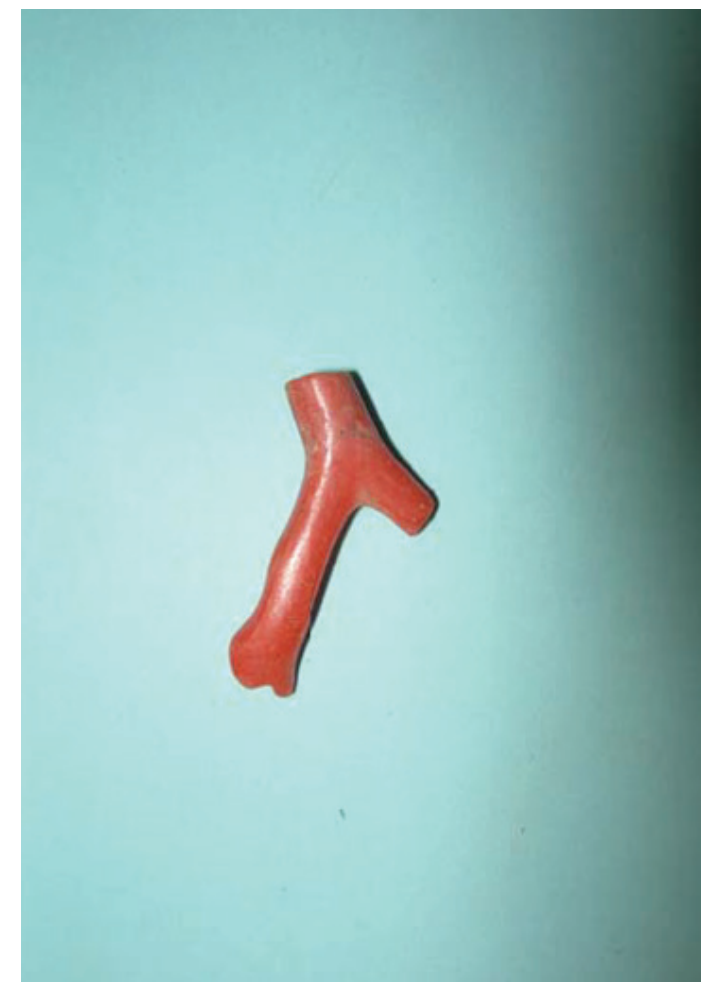

Figura 3 - Fragmento de coral vermelho. Fotografia cedida pela Dryas, Arqueologia.

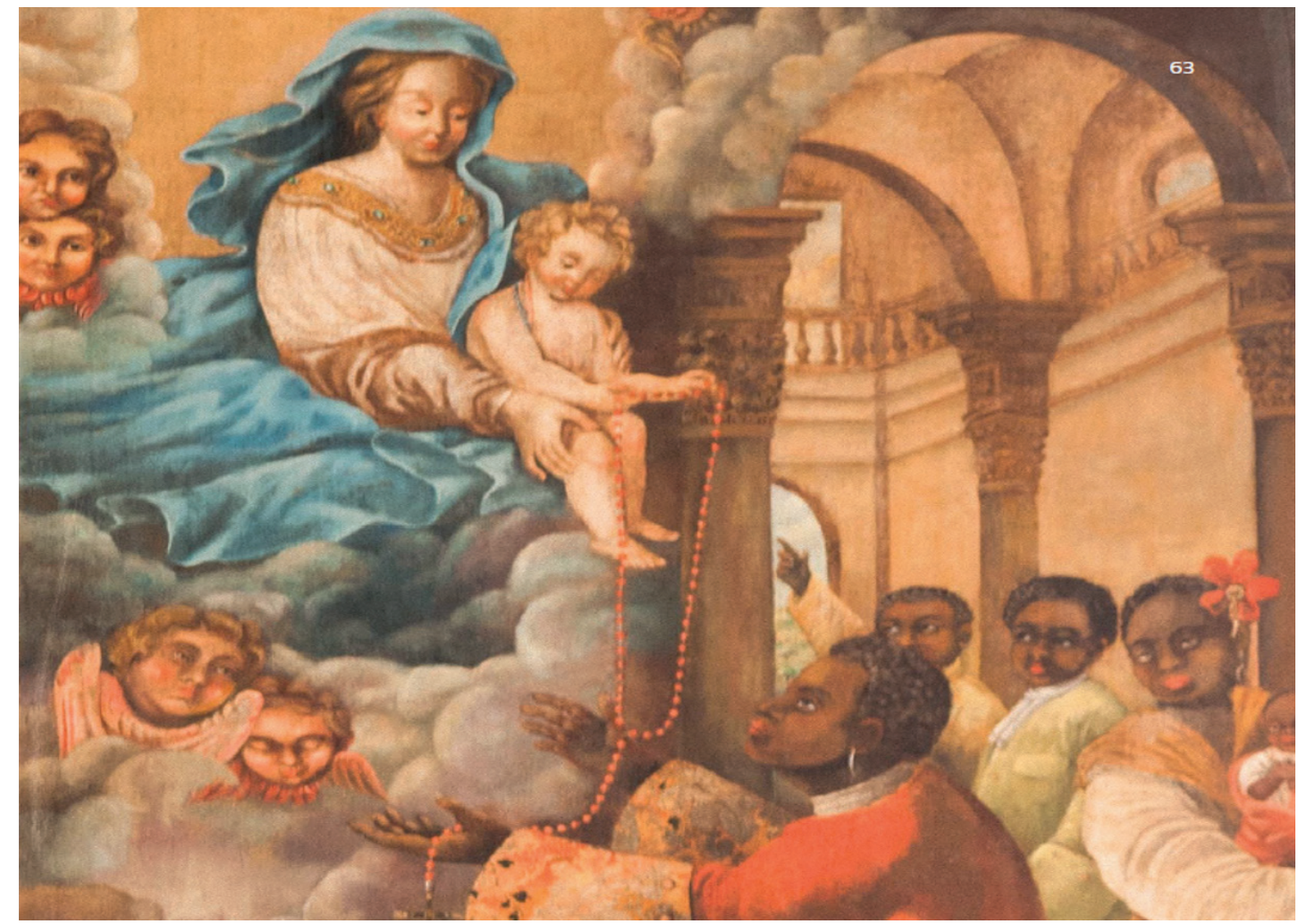

Figura 4 - Nossa Senhora do Rosário, Igreja de S. Pedro. Fotografia cedida pela Paróquia de S. Pedro de Faro. 

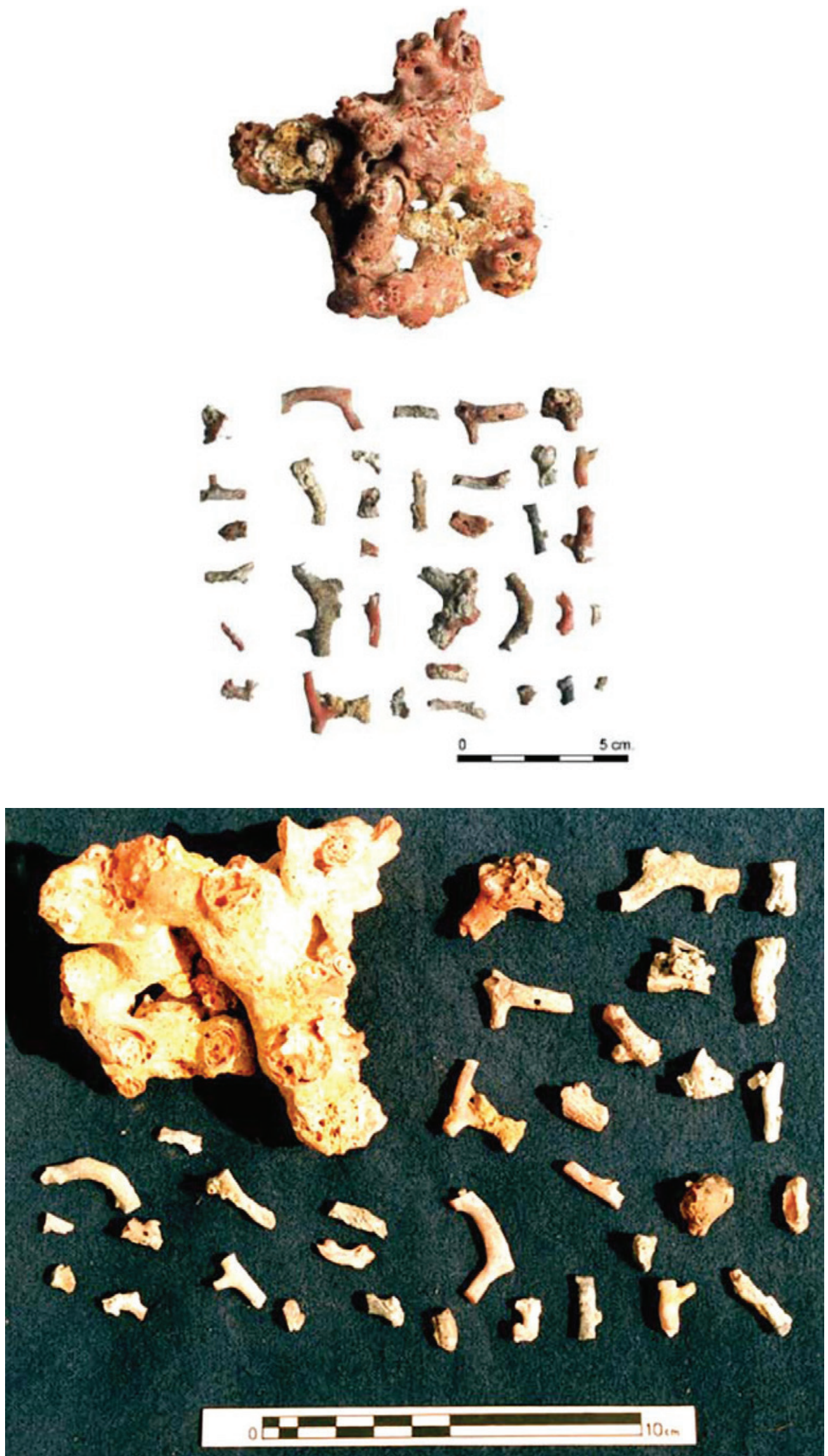

Figura 5a e 5b - Trinta e cinco fragmentos de coral vermelho recuperados em 1996 por Mário Jorge Almeida. Fotografias cedidas por Mário Jorge Almeida. 


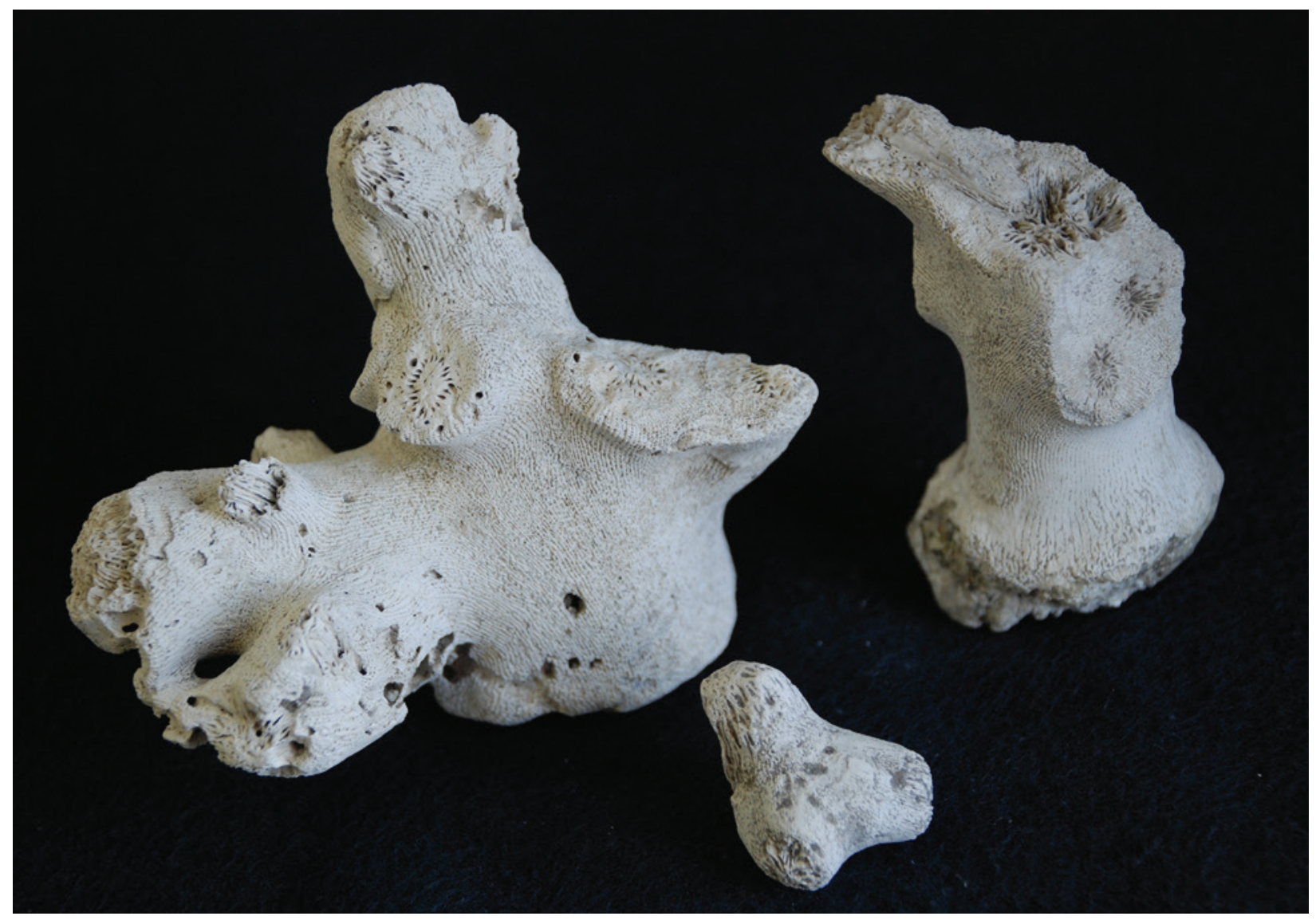

Figura 6 - Fragmentos de coral branco, Vila do Conde. Fotografia cedida pelo Gabinete de Arqueologia Municipal de Vila do Conde. 



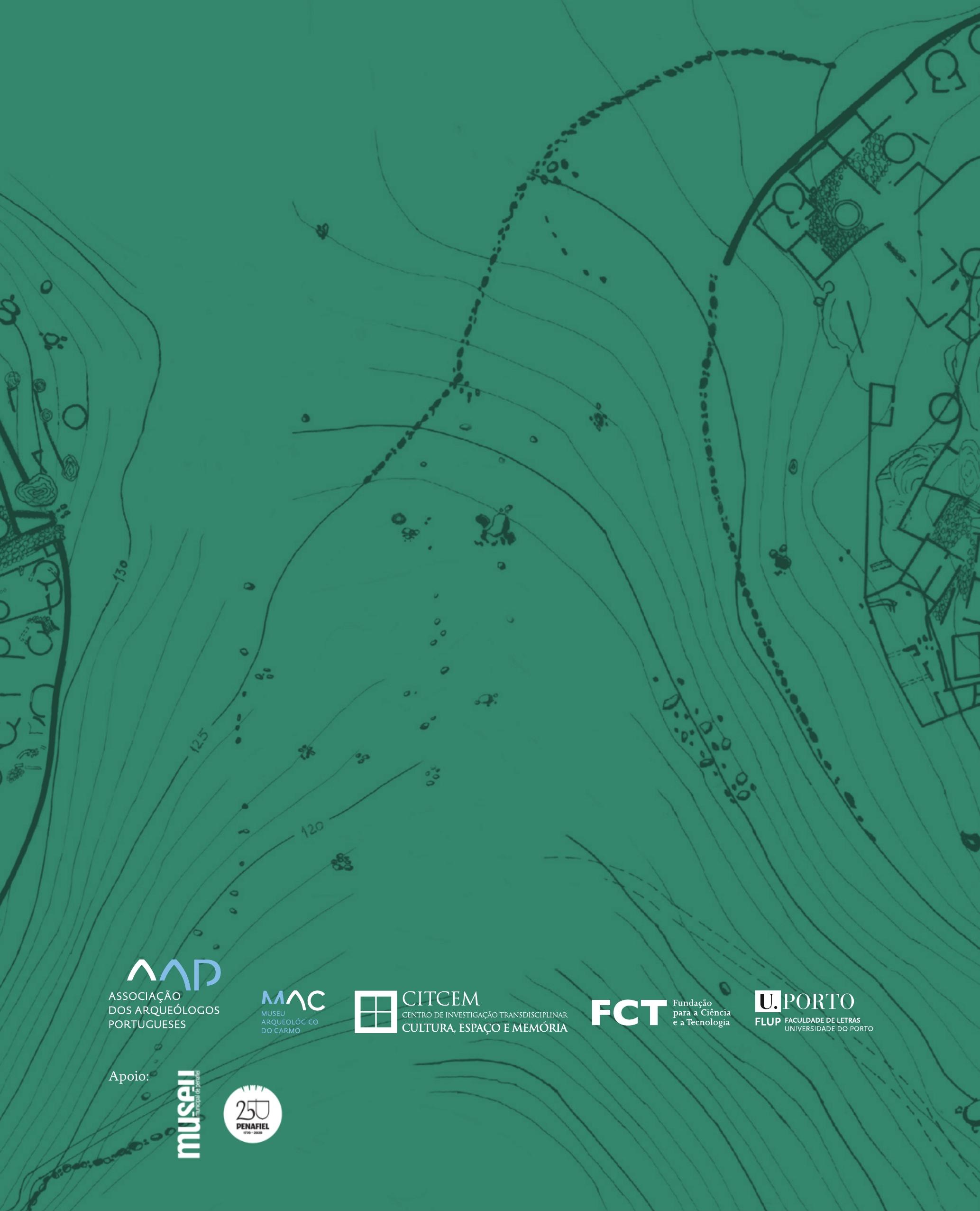

